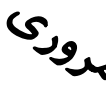

كاربردهاى ميدانى رسوب ميكروبى كربنات كلسيم در بهسازى خاك؛ جالشها و فرصتها

\author{
مهدى ملكى كاكلر * و محسن ياورى'
}

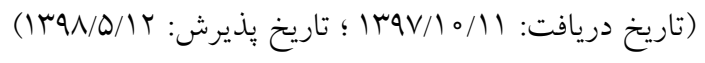

جكيده

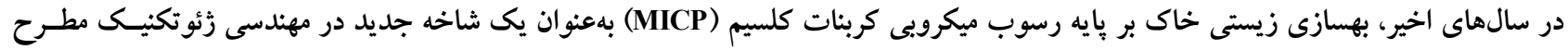

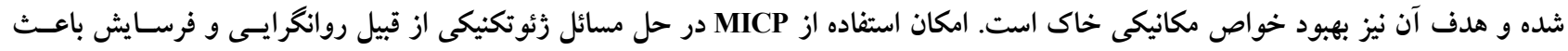

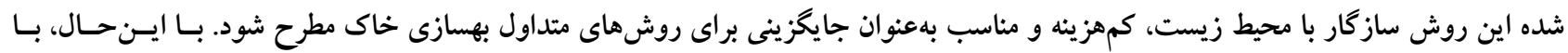

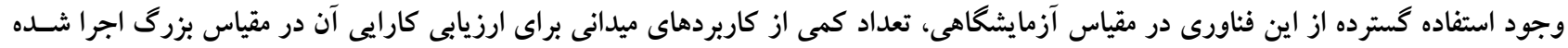

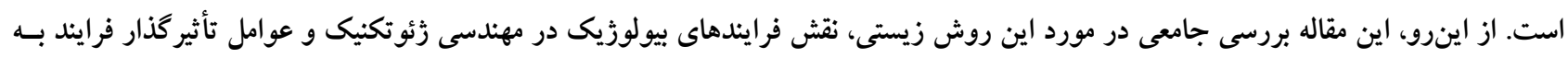

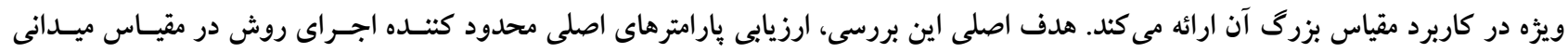

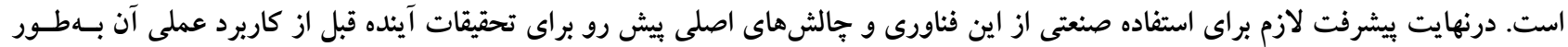
خلاصه مورد بحث قرار مى ثيرد.

وازههاى كليدى: سيمان بيولوزيك، اورهآز، رسوب ميكروبى كربنات، مقياس ميدانى 
مىتوان علاوه بر تثبيت خاكهاى روان بهمنظور جلو گيرى از

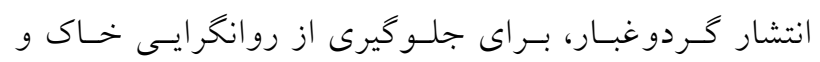

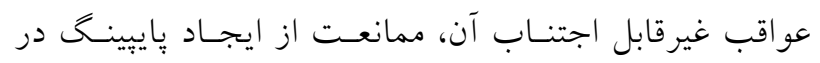

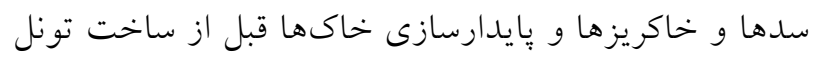

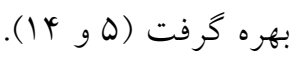

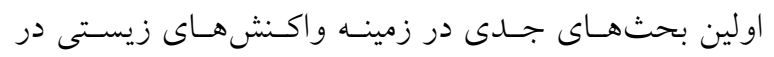
مهندسى زئوتكنيك را ميجل و سـانتاماريا در سـال هـب ب ارائسه

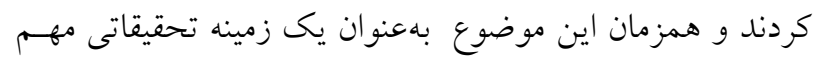

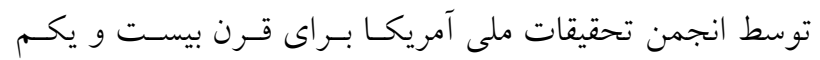

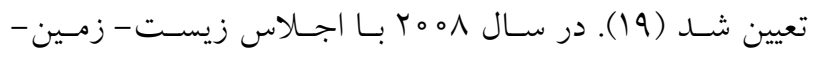

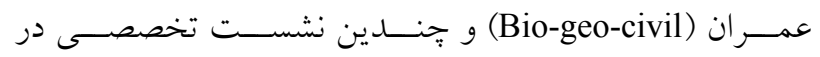
اجلاسهاى ملى و بين المللى، مقالاتى در مورد يّانسيل استفاده

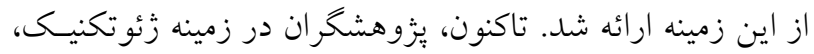
برنامهاى تحقيقاتى جندرشـتهاى (Multidisciplinary studies) را براى توسعه استراتزىها و ييشبرد اين زمينهه در حسال ظهـور با هدف شناسايى جالشهاى اصلى و فرصتهاى ييش رو رو انجام

(V) دادهاند اين تحقيق به نقش فناورى بهسازى زيستى خاك بـر بايـهـ

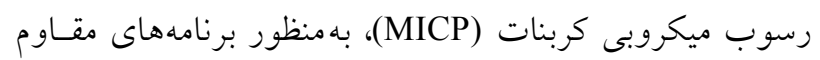

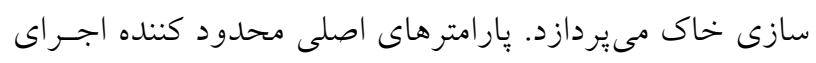

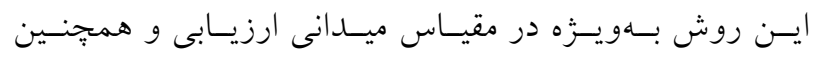

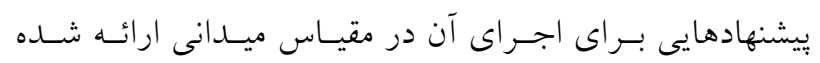

\section{مكانيسم اثر رسوب ميكروبى كربنات كلسيم}

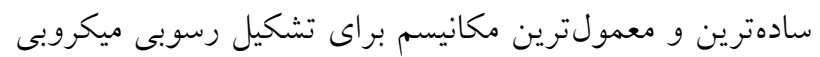
كربنات استفاده از يك باكترى يوروليتيك (Ureolytic bacteria)

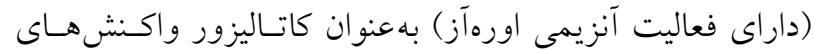

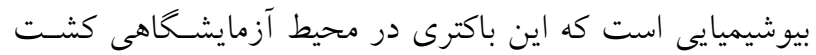

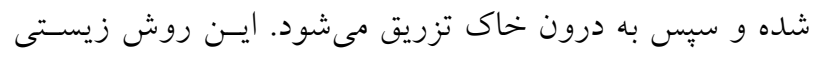
با استفاده از بـاكترىهـاى يوروليتيكى كـه در خـاك و محسيط زيست طبيعى بهوفور بافت مى شوند، مى تواند باعـث سـيمانى بوريني

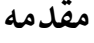

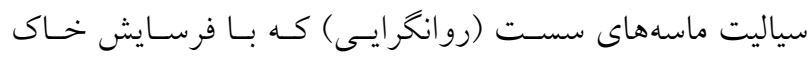

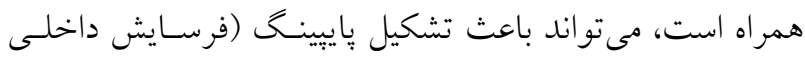
رسوبات شن و ماسه توسط مجراى جريان آب زيرزمينى) شــده

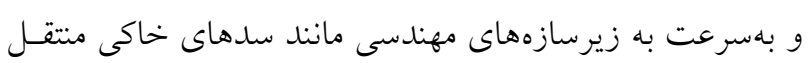

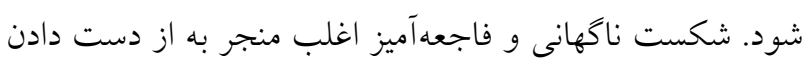

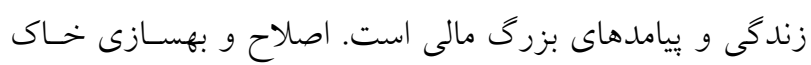

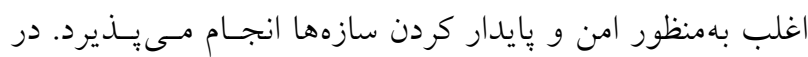

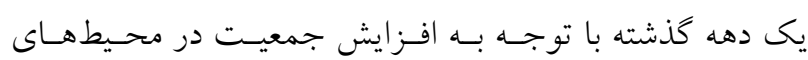
شهرى و كاهش محيطهاى مناسب براى ساختمانسازى، نياز به بهسازى افزايش يافته است (r).

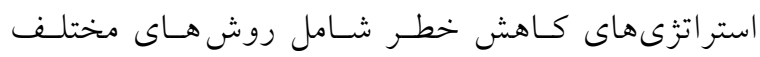

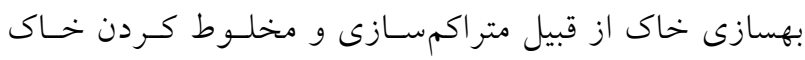

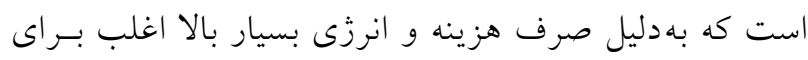

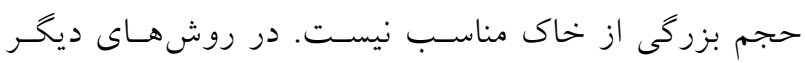

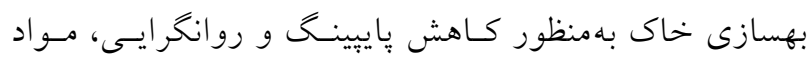

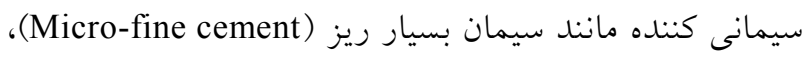
ايوكسى (Epoxy) و يلى اورتسان (Polyurethane) بـه درون

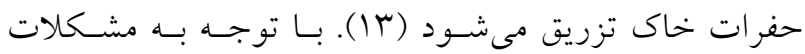
زيست محيطى ايجاد شده و نيز مسئله انرزى مصـرفى بـالاى

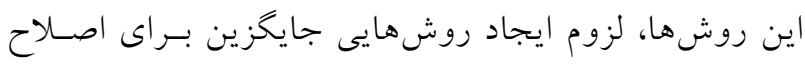

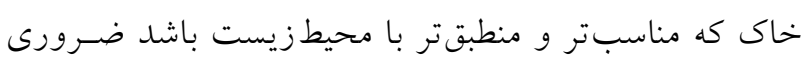

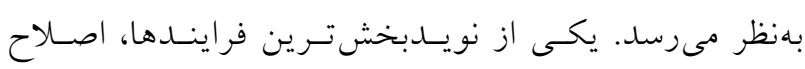
زيستى خاك با استفاده از رسوب ميكروبـى كربنـات كلسـيم (MICP: Microbial Induced Carbonate Precipitation) است كه در آن فراينـــ زمسين - شـيميايى اصـلاح خـاك بـا

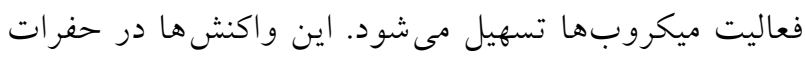

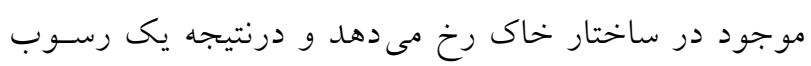

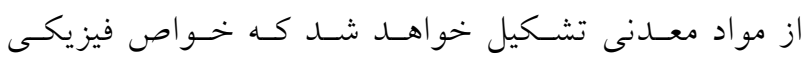

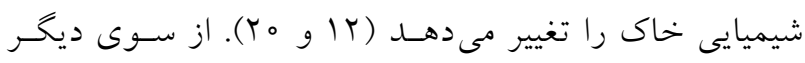
اين روش اصلاح داراى مواد مصرفى ارزان و كم خطر است دهي

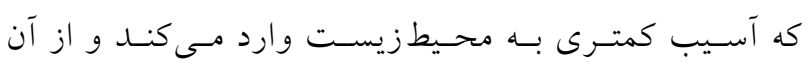




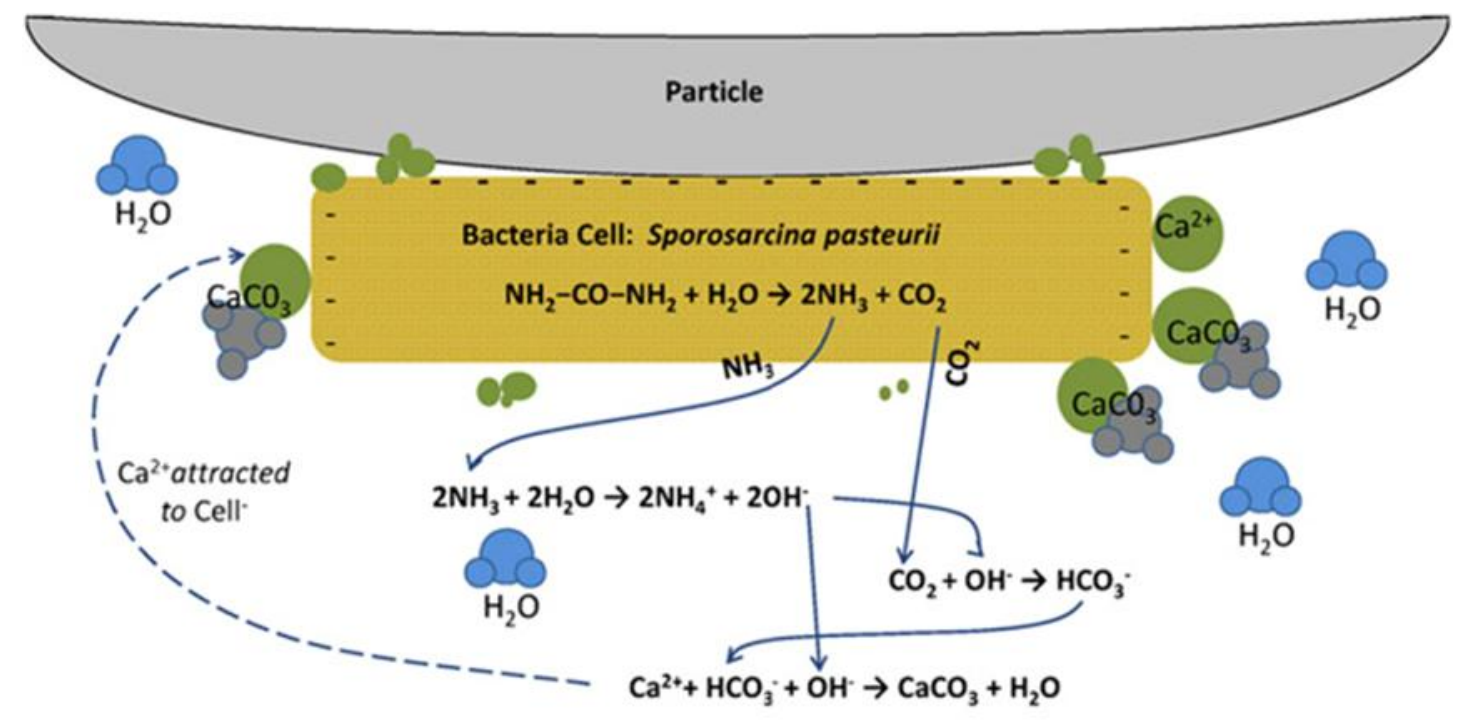

شكل ا. نمادينى از رسوب بيولوزيك كلسيت درون ساختمان خاك (ه)

يوشانده مىشوند. درنهايت با محدود شدن تدريجى انتقال مـواد مغذى سلول باكتريايى احاطه شده در ميان رسوبات از بين رفته و مواد زائد از سيستم خارج مىشود (شكل r) (V). بيشـترين مطالعـات رسـوب ميكروبـى كربنــات از طريـق هacillus pasteurii هيــدروليز اوره بــا اســفـاده از بـــاكترى

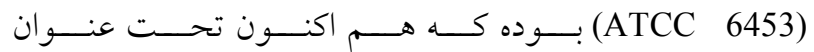
طبـــــ Sporsarcina pasteurii (ATCC 11859) است. مواردى از قبيل حساسيت كم تحت شرايط غلظت بـالاى نمك، فعاليت آنزيمى بالا ( آ⿱) و عدم لخته شدن (r) را مى توان از جمله دلايل استفاده كسترده از اين باكترى دانست.

$$
\text { عوامل مؤثر در كنترل كارايى MICP }
$$
كارايى فناورى زيستى MICP بستكى مستقيم با توزيـع فضـايى رسوب ميكروبى و همجنين نوع كريستال تشكيل شده كربنـات

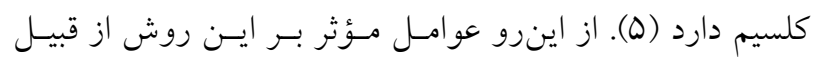
فعاليت آنزيمى، دسترسى به محـل هـاى هسـتهزايسى، pH دمـا، درجه اشباع، غلظت محلولهاى واكنش دهنده، نرخ تزريق مواد مغذى، عمق نفوذ باكترىها و منحنى دانهبندى خاك بايد كتــرل

$$
\text { شود. }
$$

شدن قابل كنترل و در نرخ بسيار سريع (كمتر از ب ساعت) در مقايسه با سيمانى شدن شيميايى شود (ه). مجموعه و اكنشهـاى بيوشيميايى شامل هيدروليز اوره توسط باكترى و توليد آمونيـاى و دى اكسيد كربن درنهايت منجـر بـه رسـوب زيسـتى رسـوب كربنات كلسـيم ( شيميايى كه درون توده خاك رخ مىدهد بهصورت نمـادين در شكل ا نشان داده شده است (ه). سلولهاى باكترى نيز بهدليل آنكه يون هيدروكسيد بر ديواره

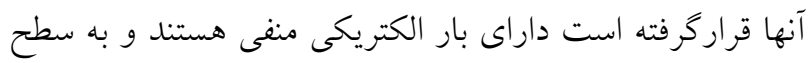
دانههاى خاى كه داراى غلظت بهنسبت بـالايى از مـواد مغـذى

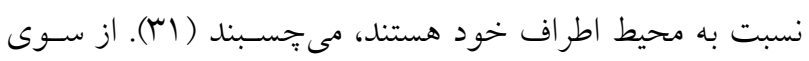
ديخر يون كلسيم نمك كلسيمدار نيز بر اثر بار منفى موجـود بـر ديواره سلول باكترى جذب آن مىشود. به محض اضـافه شـدن اوره به محيط، باكترىها يونهاى كربنات معـدنى و آمونيـوم در محيط آزاد مى كنند. در حضور يون كلسيم، ايسن امـر مسىتوانـد منجر به ايجاد محيط فوق اشباع موضعى شود كـه باعـث ايجـاد رسوب غيريكنواخت كربنات بر ديواره سلول شده كـه خــواص مكانيكى خاك بهبـود مسىيابــ. درصـورت وجـود سوبسـترا و فعاليت آنزيمى كـافى همـه سـطح سـلولهـا توسـط رسـوبات 

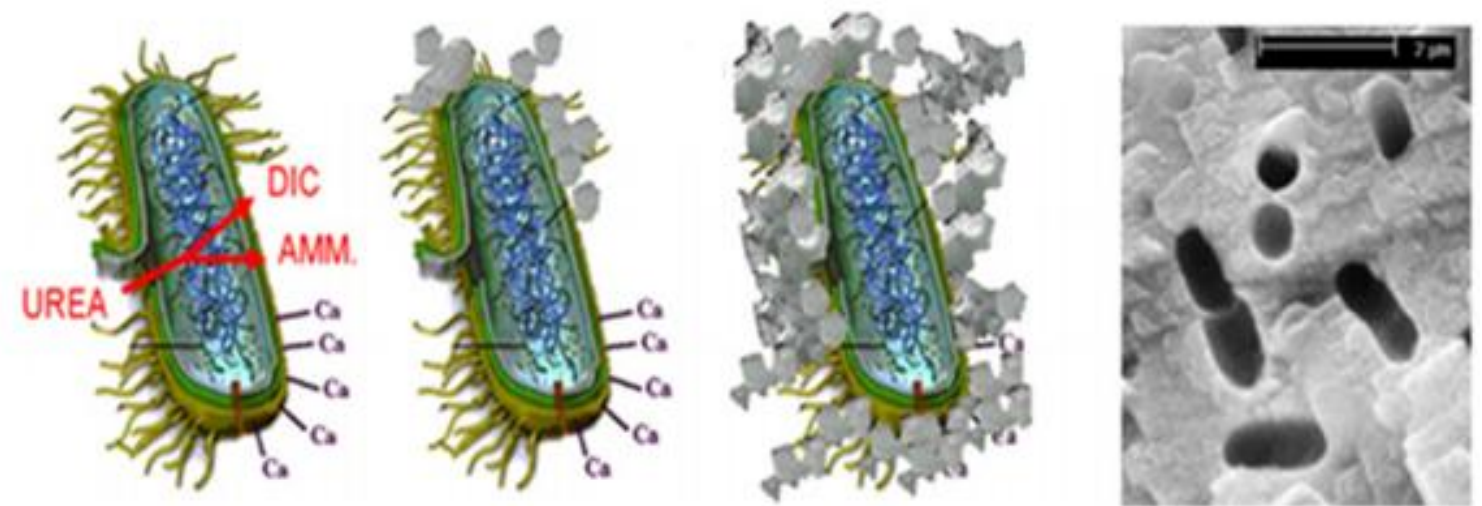

شكل r. شكل سادهاى از آنجه در حين رسوب كلسيم كربنات تحت اثر آنزيم اورهآز رخ مىدهد (V).

نسبت داد و همجنين رسوب نامناسب در خاكهاى درشتدانـه

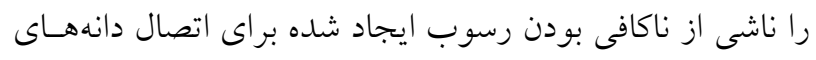

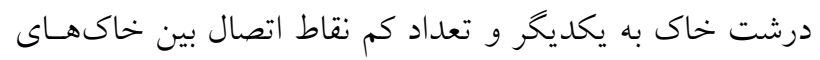

$$
\text { درشتدانه بيان كرد (Y) (Y). }
$$

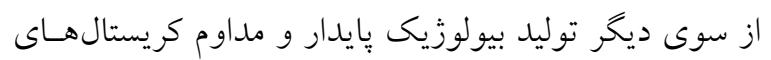

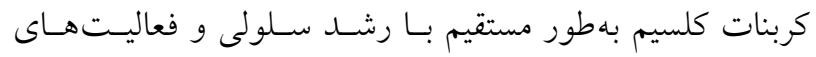

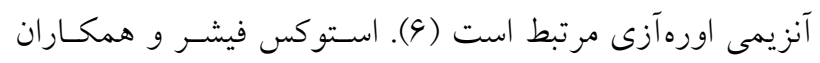

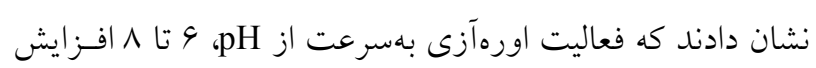

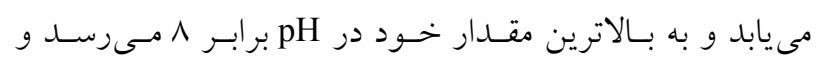

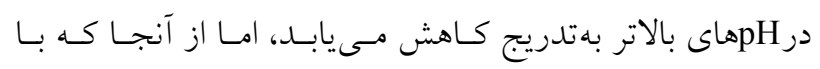

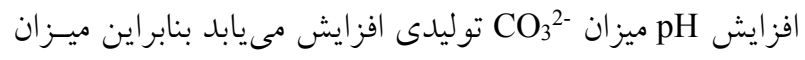

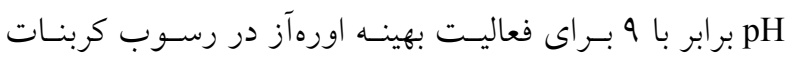

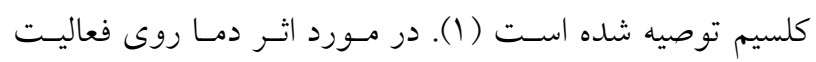

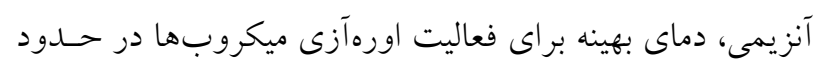

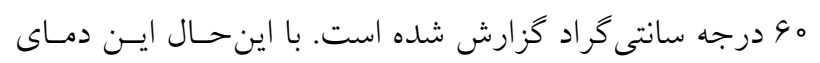

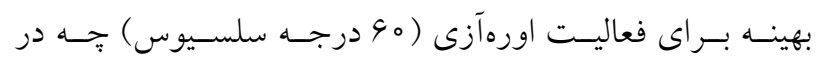

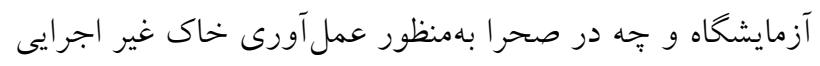

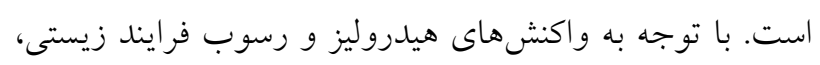

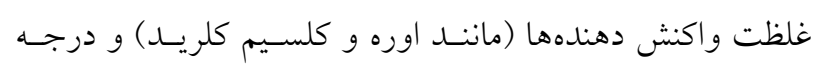

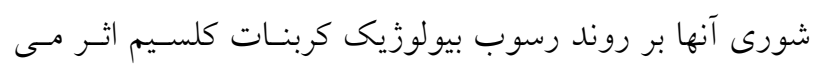

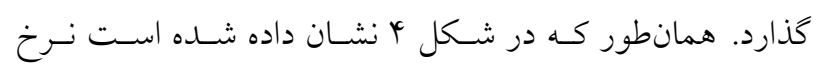

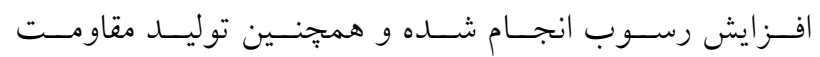

جابه جايى باكترىهـا و بـاقىمانــدن آنها درون شـبكه حفــات

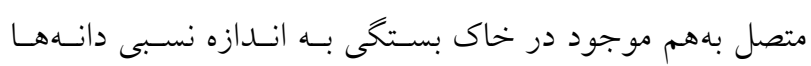

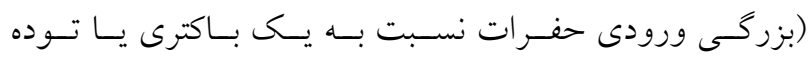

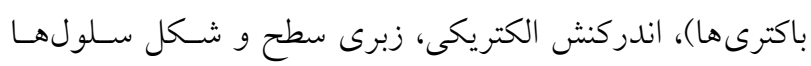

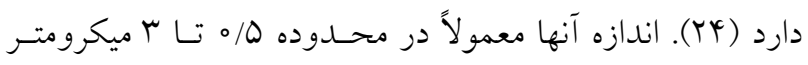

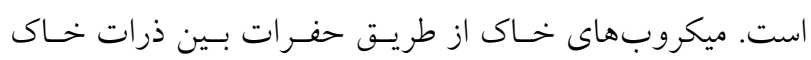

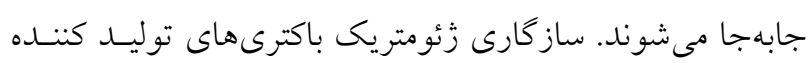

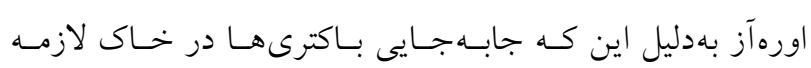

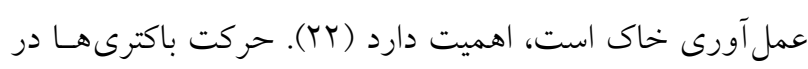

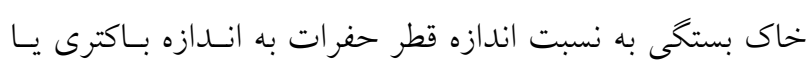

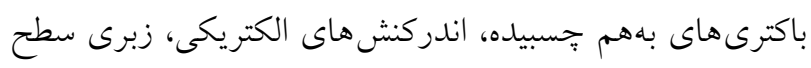

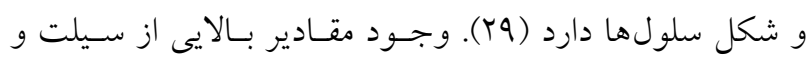

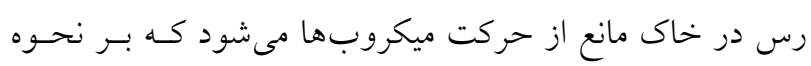

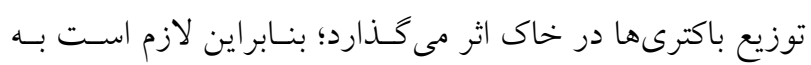

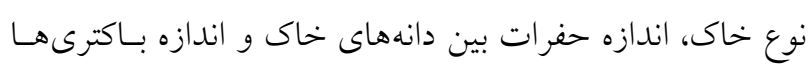

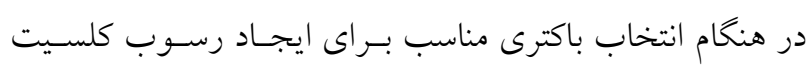

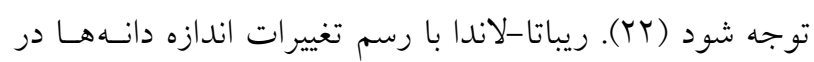

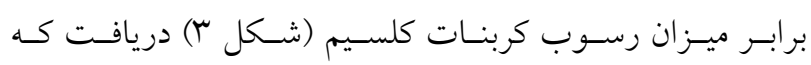

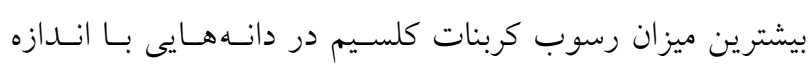

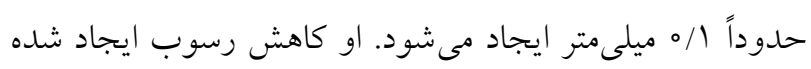

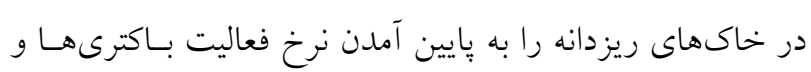

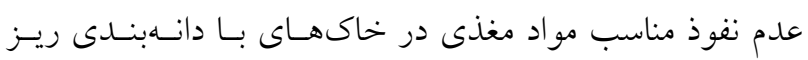




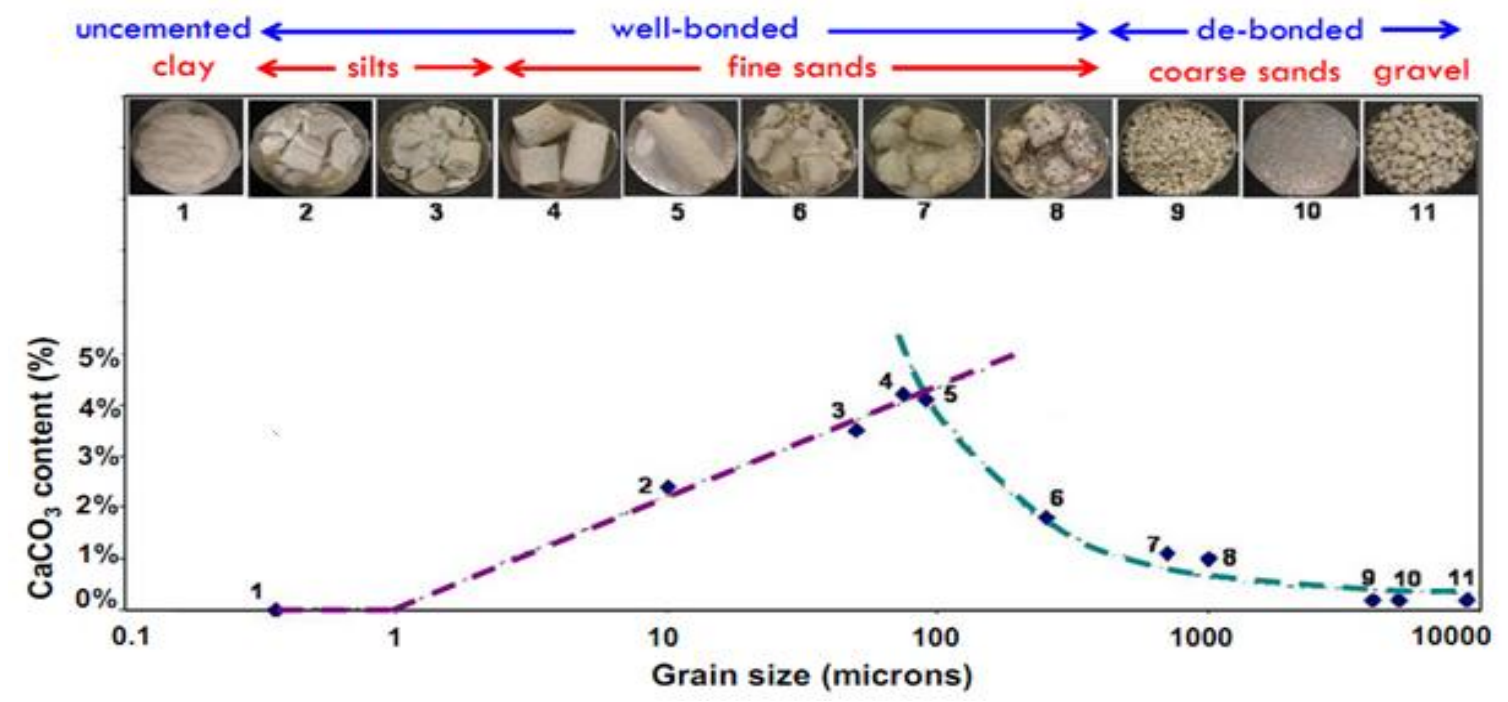

شكل r. تغييرات مقدار منحنى دانهبندى با تغيير اندازه دانهها (YF)

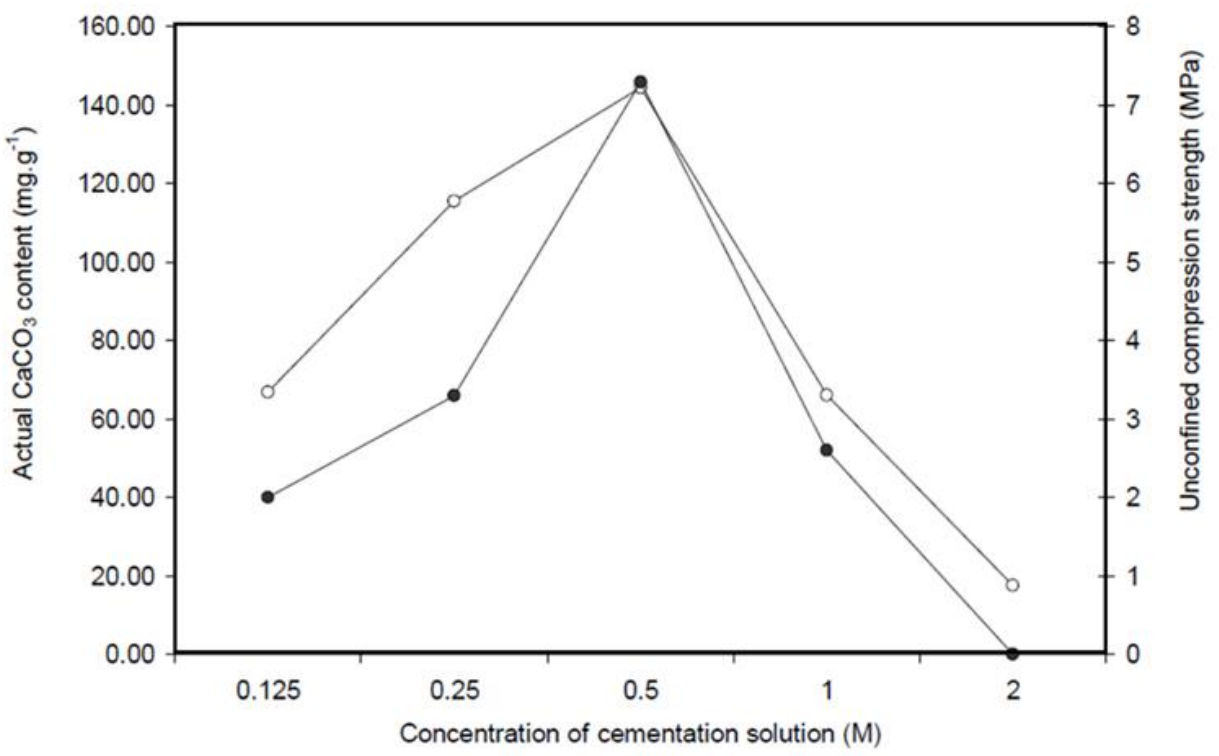

شكل ثا. تأثير افزايش غلظت كلريد كلسيم در نرخ رسوبكذارى (O) و افزايش مقاومت (•) در ستون ماسه (1)

كاملاً بستخى به غلظت كلسيم دارد. البته روند افزايش رسوب با مانند روش تزريق و غلظت واكنشدهندههـاى شـيميايى كنتـرل

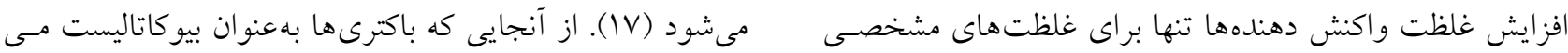
حاكم است. درجه شورى بالا كه بيشتر تحت تأثير نمك كلسـيم توانند باعث تشكيل

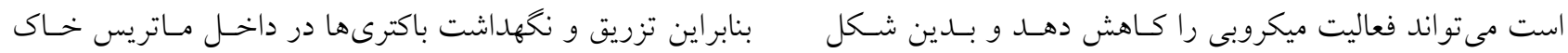

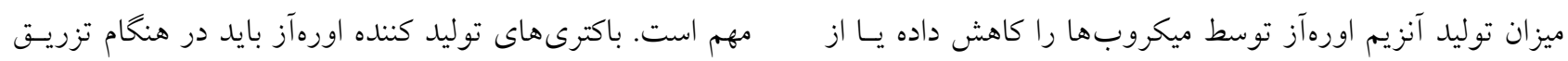

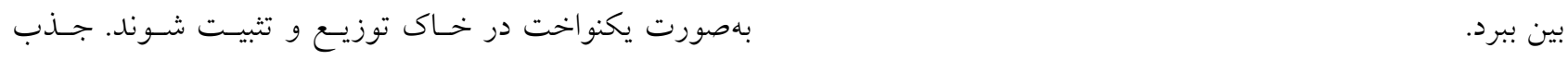

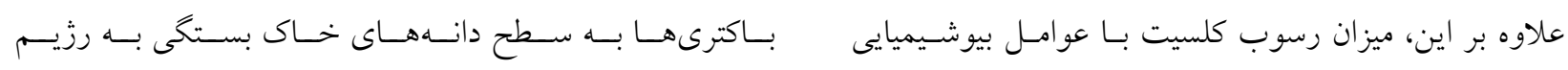




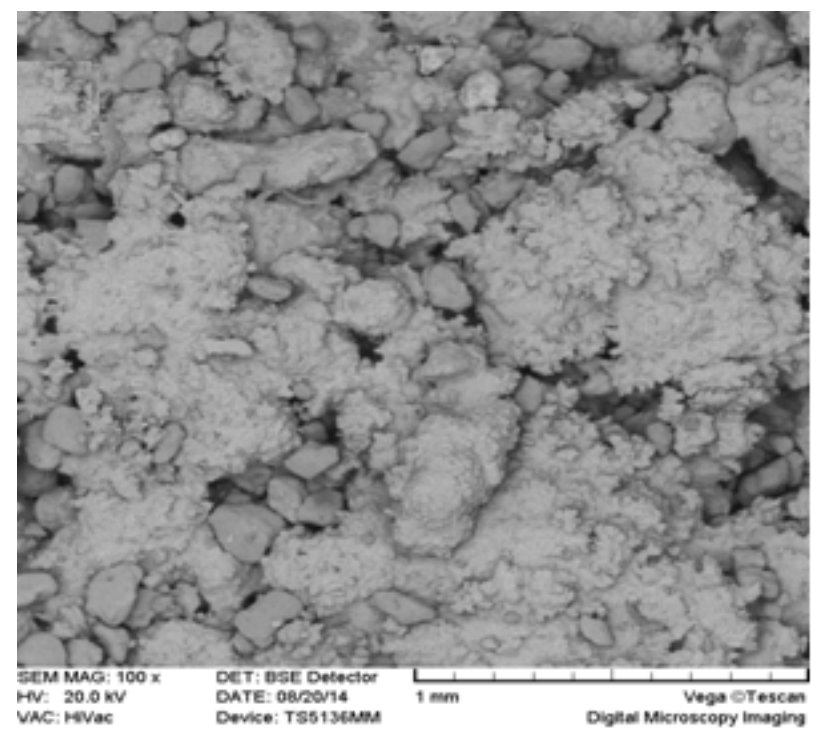

شكل ه. ماسه عمل آورى شده تحت تزريق بيش مخلوط به همر اه باشش (IF)

مطالعات انجام شده توسطط التـاودى (Al-Thawadi) بـا اضـافه كردن يون كلسيم به محلول باكترىها ميزان خسبيدن باكترىهـا

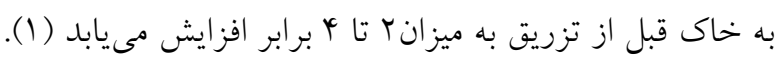
مطالعات وسيعى بر روش مناسـبتــر و مطلـوبتــر ايجــاد

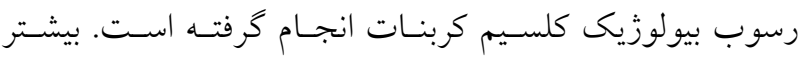
تحقيقات انجام شده بر ايجاد رسوب بيولوزيك كلسيم كربنـات با استفاده از روش تزريق بوده است كه مشـابه تزريـق دوغـاب

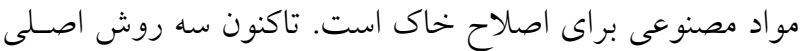

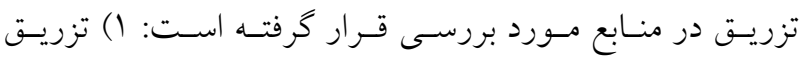
محلولهاى واكنش دهنده (محلـول سمانتاسـيون و بـاكترى) در

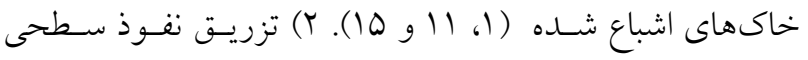
(Surface percolation)

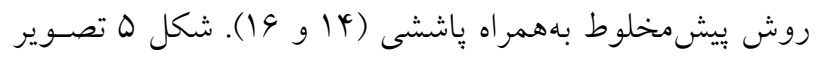

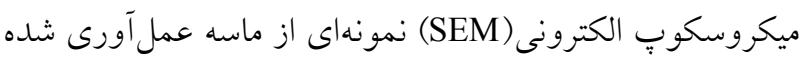

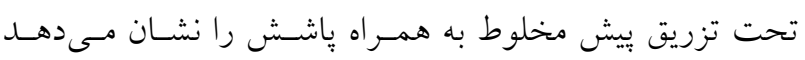

بررسى اثر غلظت محلول واكنش دهنـــه بـا تزريـق غلظـت هاى برابر محلول كلسيم كلريد و اوره نشان مى دهد با تغييـرات

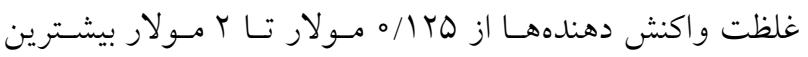
ميزان رسوب كربنات كلسيم در غلظت ه/ه مولار اوره و كلسيم
جريان، ويزّكىهاى ديواره سلولى و بـار الكتريكسى سـطح آنها،

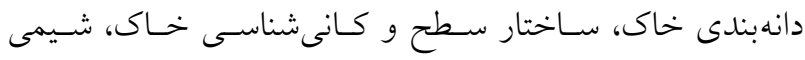

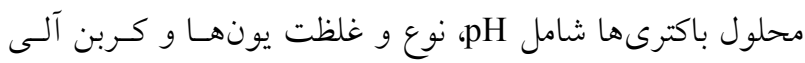
حل شده دارد (11). همجنين روش هاى نامناسب تزريق ممكسن

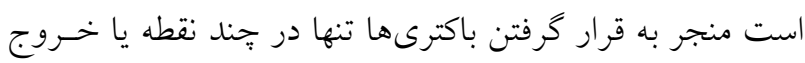

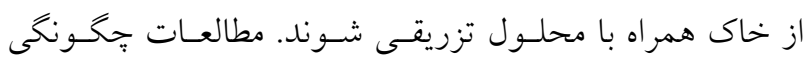

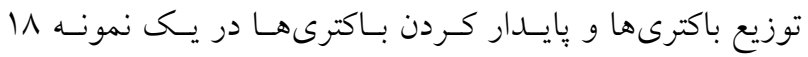

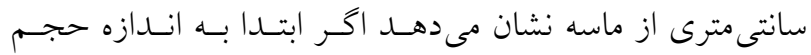

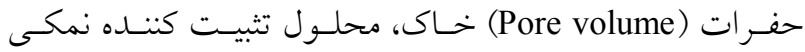
(شامل محلول كلسيم كلريد 00 ميلى مـولار) و ســس مححـول

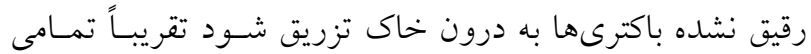

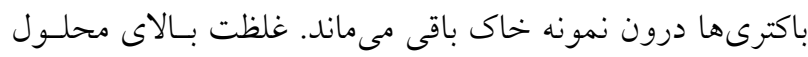

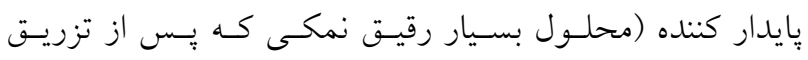

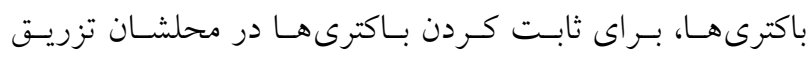

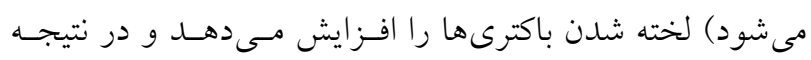

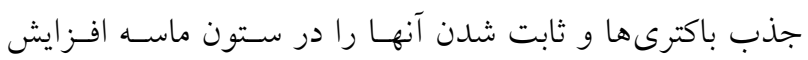

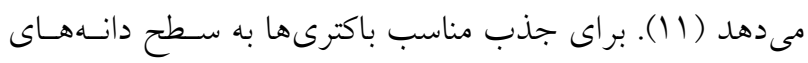

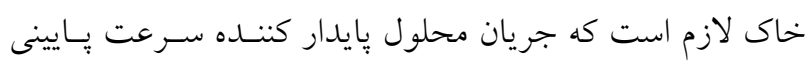

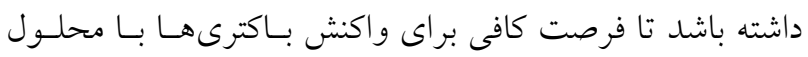

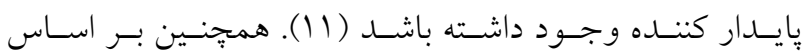


فرايند اصلاح و بهسازى زيستى خـاك، مقاومـت خـاكهـاى

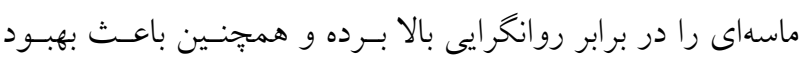

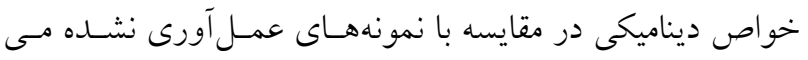

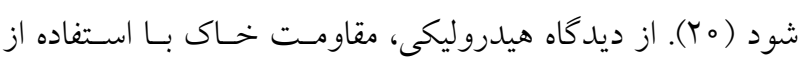
روش MICP افزايش يافته درحالى كه كاهش شــيد نفوذيـــيرى

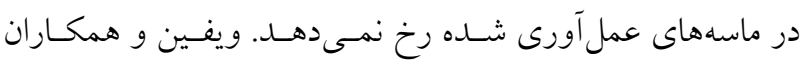

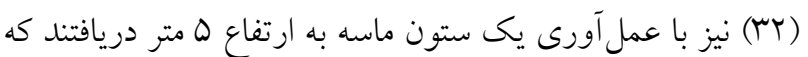
ميزان نقوذيذيرى در همه ستون تا حدودى كاهش مى يابد اما ايسن

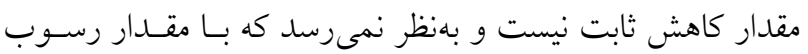

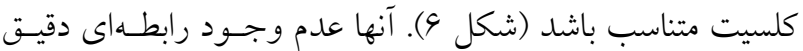
بين نفوذيذيرى و ميزان كـاهش آن را بـهدليـل نـاهمخنى تشكيل رسوب كربنات كلسيم در طول ستون خاك توجيـه كـردانـــ. بـا

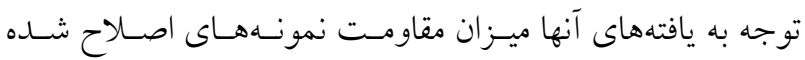
بيولوزيك بهطور جشمخيرى تحت تأثير ميـانخين مقـدار رسـوب لهاب كربنات كلسيم ايجاد شده اسـت درحسالى كـه نفوذيـــيرى بيشـتر

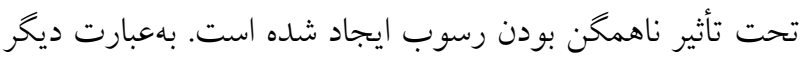

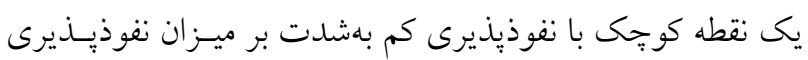

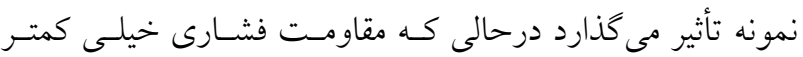

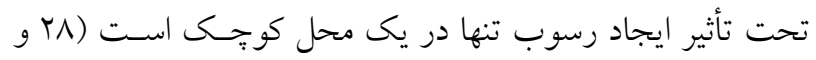

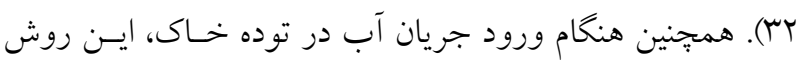

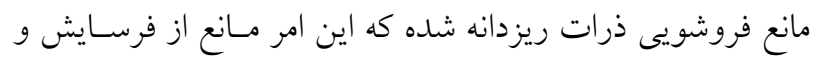
رسوب داخلى خاك مى شود.

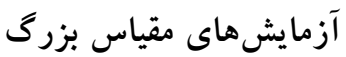

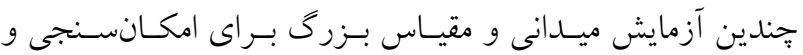
كارايى MICP در محل بهسازى خاك انجـام شــه اسـت. اولـين تلاش در مقياس كامل براى بهســازى منطقـهـ بنــدرى روتـردام در

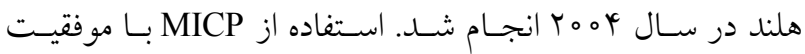
نقوذيذيرى خاك ماسهاى را كاهش و همجنين عملكرد خـوبى را

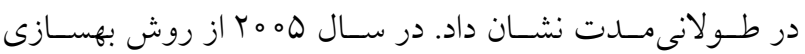
زيســى بــراى جلــو گيرى از نفــوذ آبهــاى شـور زيرزمينسى در

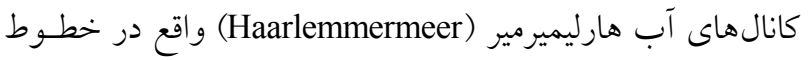

كلريد حاصل مى شود ( ). از سوى ديخــ توزيـع كريستالهـاى

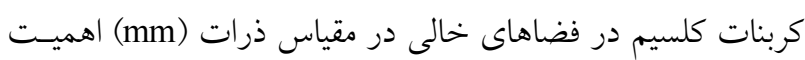

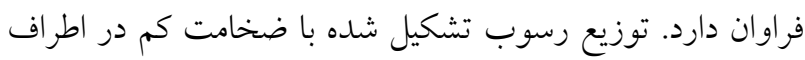

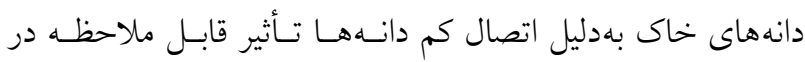

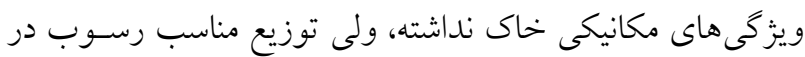

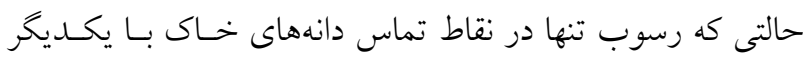

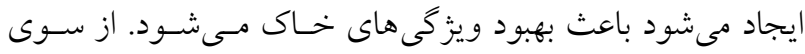

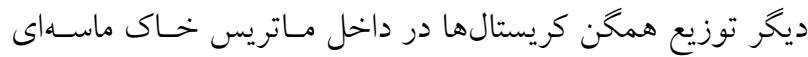

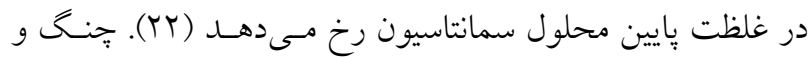
همكاران (Y) نشان دادند كه مقاومت بالاى MICP ايجاد شده در حالـت غيراشـباع بـهدليـل تشـكيل كريسـتالهــاى كلسـيت در مكانهاى مؤثر ميان ذرات خاك است.

\section{ويزّكىهاى مهندسى بهبود يافته خاك}

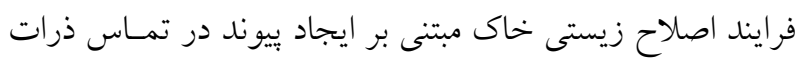

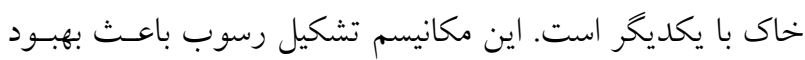

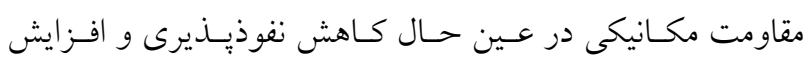

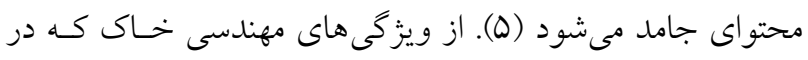

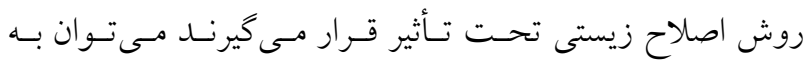

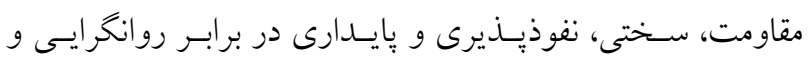

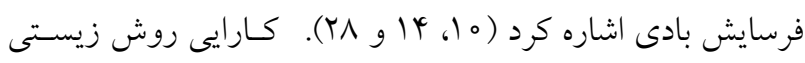

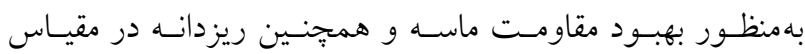

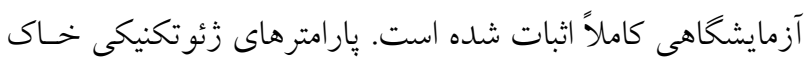

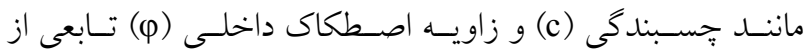
محتواى كريستالهاى كلسيت رسوب شده هستند (Y). بسيارى از

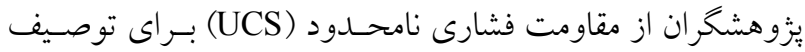
استحكام ماسههاى عمل آورى شده زيستى اسـتفاده كـردهانــ كـهـ نتايج حاصل حاكى از رابطـهـ مستقيم مقاومـت نمونـهـ بــا مقــدار

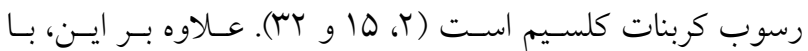

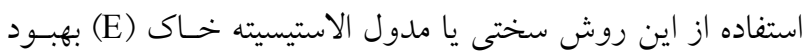
يافته (Y) و سختى برشى حداكثر (Small-strain shear stiffness)

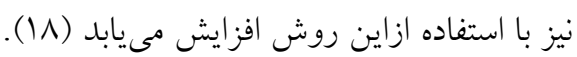




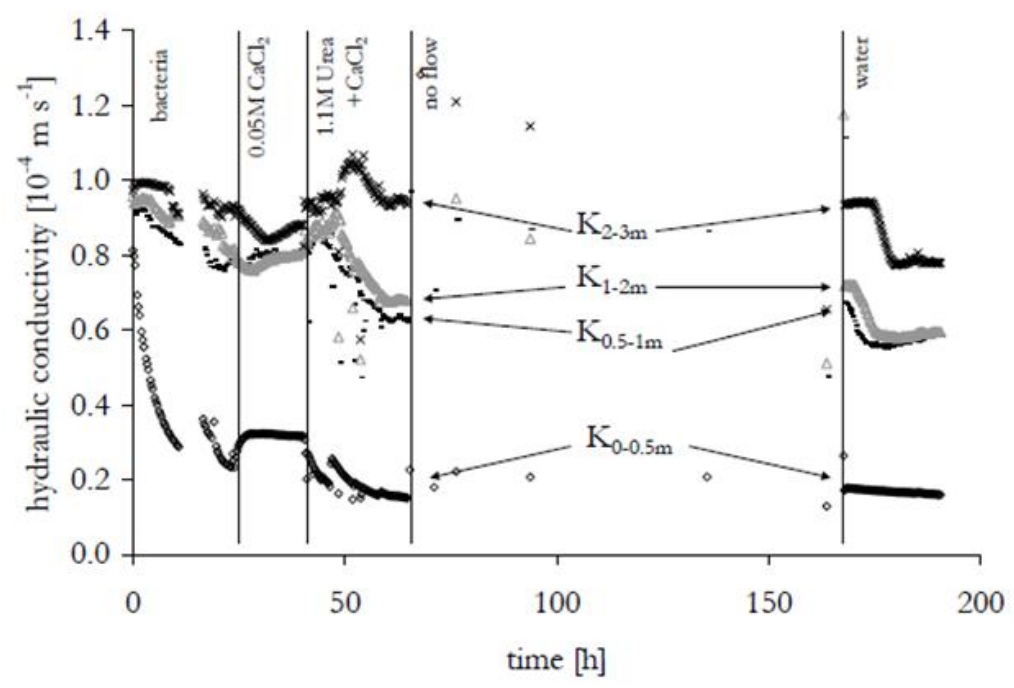

شكل 9. كاهش نفوذيذيرى در طول ستون بهدست آمده بعد از عمل آورى بيولوزيك (YN)

خشك متوسط 1090 kg/m عمل آورى كرد (شكل 9) (Y9). در اين عمل آورى، محلول بهصورت بيوسته از سه جـاه تزريـق

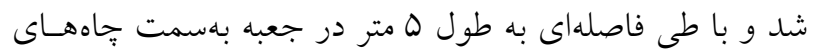

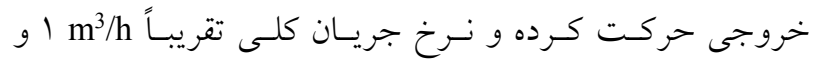

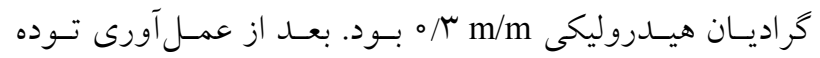

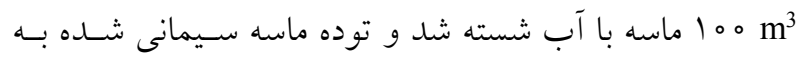

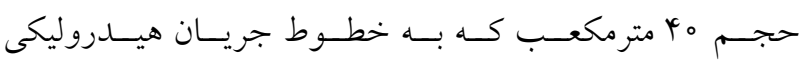

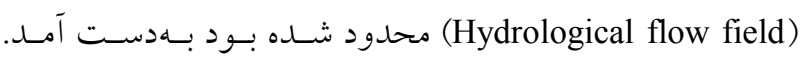
خطوط جريان بهويزه در نزديكى جاههاى خروجى بـه سـهولت ديلده مىشود (شكل ه ا- الف).

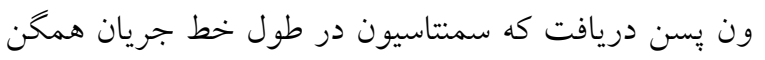

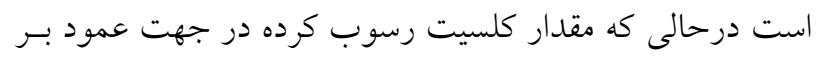
جريان بهشدت تغيير مى كند. همجنين با ايجاد يك مقطع قـائم

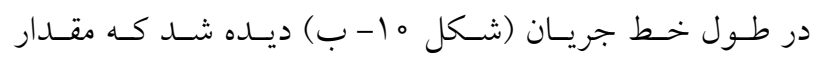

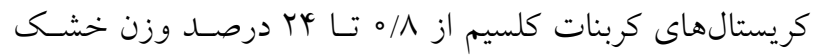

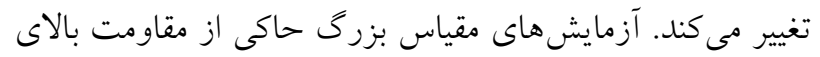
ايجاد شده در اثر رسوب كربناتى بود، با اينحال توزيــع مفــدار

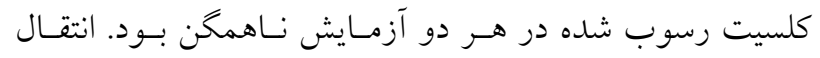
ناهمخن واكنشخرها و مسيرهاى ترجيحى جريان كـه منجـر بـهـ افزايش محتواى كلسيم كربنات در آن نقاط در مقايسه بـا سـاير
راهآهن بِرسرعت آمستردام -ِياريس بهره كَرفته شـــ (شكل

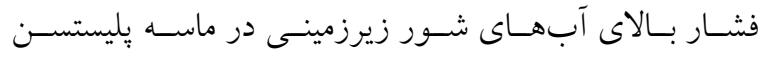
باعث جريان آبهاى شور بهسمت بالا مىشد كـه با توجه به اكوسيستم يبيجيده و حساس منطقه هارليميرمير استفاده

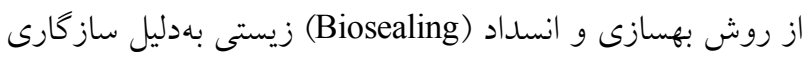

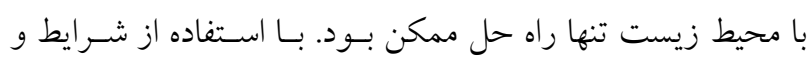

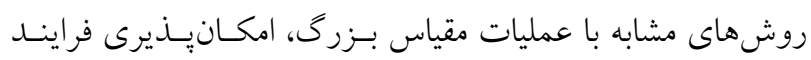

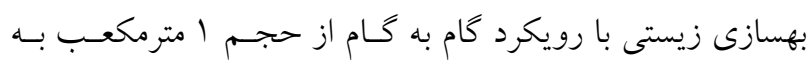

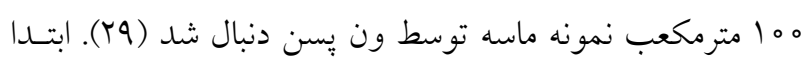

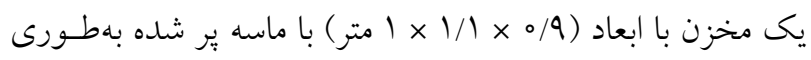

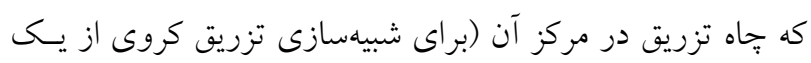

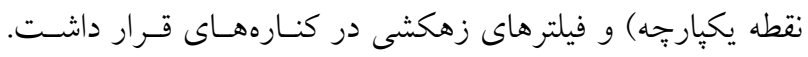
سوسبانسيون باكتريايى و محلولهاى واكنش دهنده سيمان كنتــه

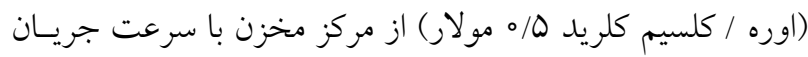

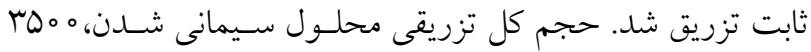

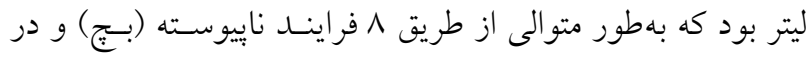
طول مه روز تزريق شد (شكل ه).

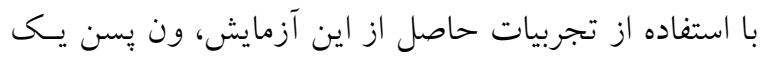

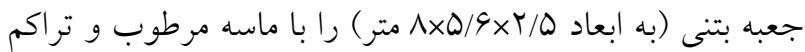




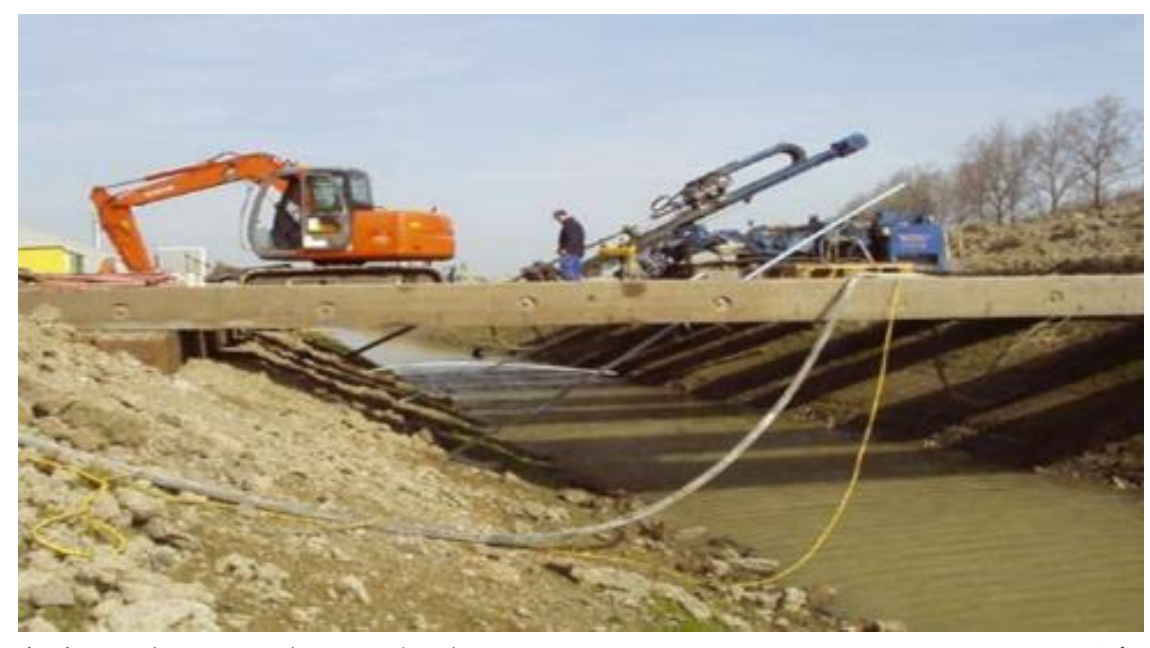

شكل V. استفاده از روش بهسازى و انسداد زيستى در كانال قطار سريعالسير در هارلمرمير (Y\&)

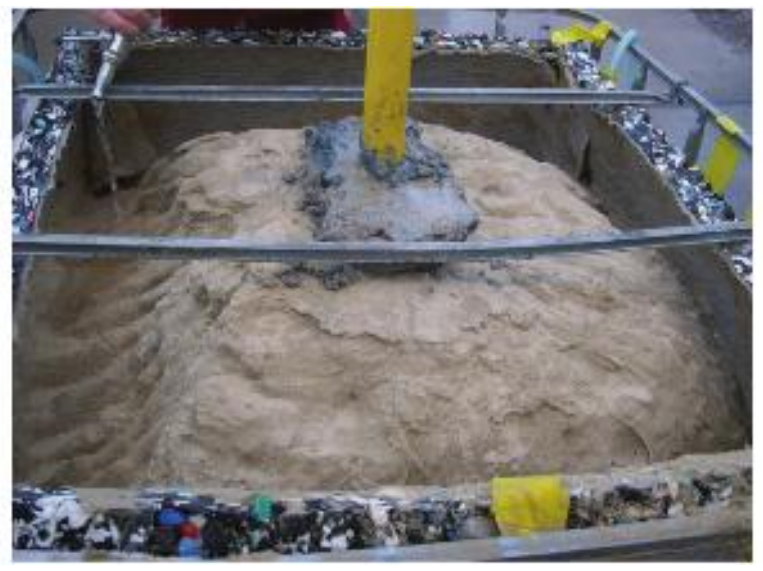

شكل 1 خاك عمل آورى شده بهروش زيستى در آزمايش با حجم ا متر مكعب (Y)

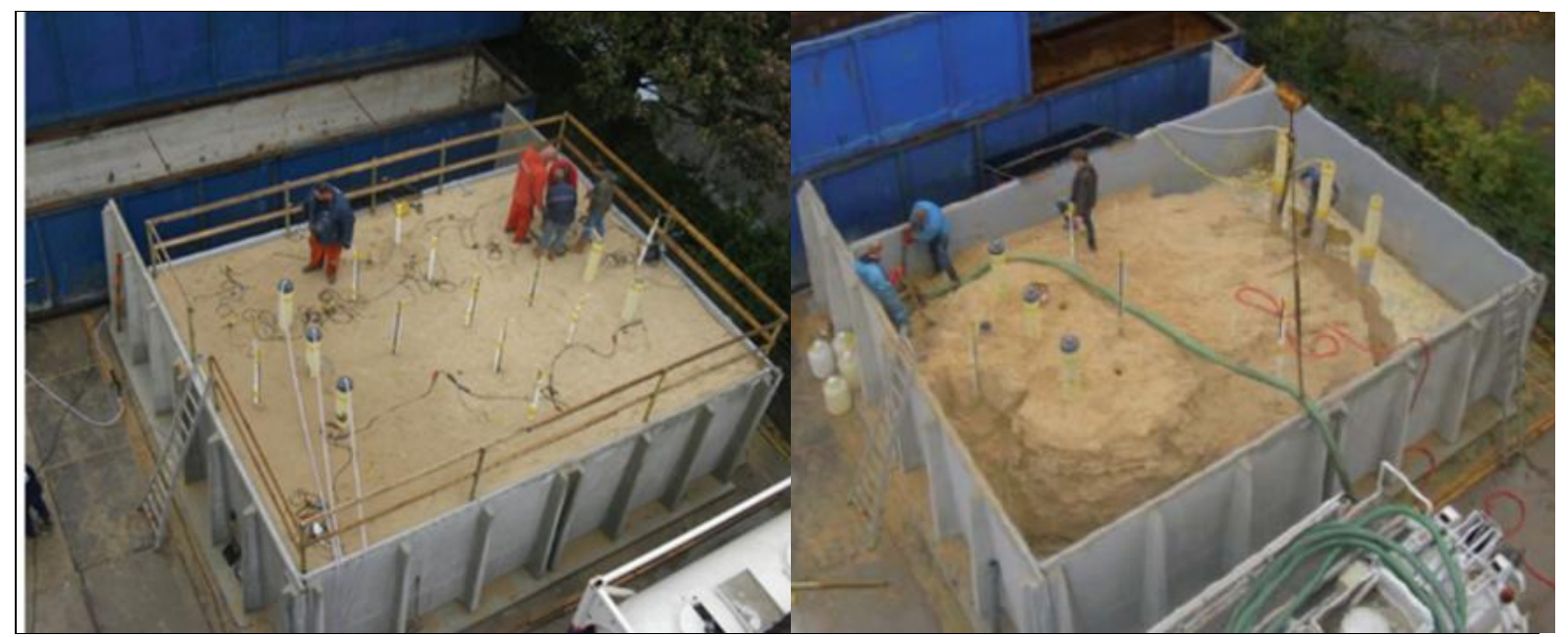

شكل 9. آزمايش بزرگ مقياس ( m¹00) شامل سه جاهك تزريق و سه جاهك تخليه براى تزريق محلول به حجم خاك

قبل و بعد از عمل آورى (Yq) 


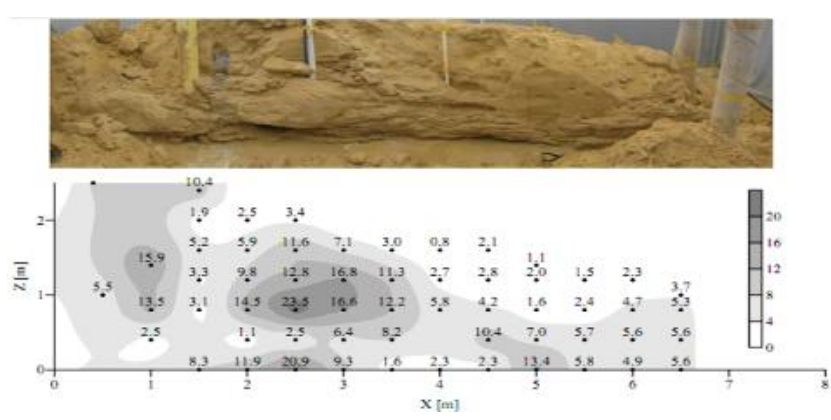

ب) مقطع طولى عبورى از وسط جاهكهاى مركزى كه مقدار كربنات كلسيم را نشان مىدهد.

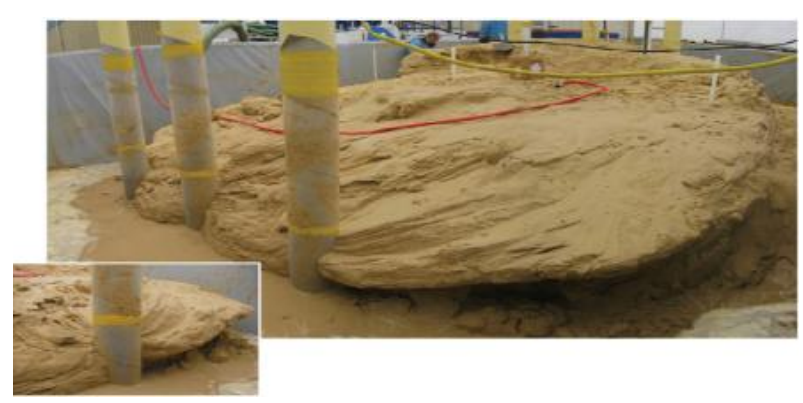

الف) الكوى سيمانى شدن توده سيمانى شده به حجم $100 \mathbf{m}^{3}$

شكل • ا. الكوى سيمانى شدن و توزيع آن در آزمايش بزرگمقياس تزريق (

كه در آن ه ناحيه (تزريق / استخراج) بــراى محـدودهاى بـه انـدازه

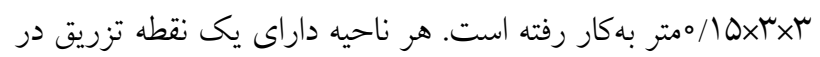

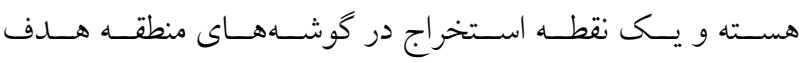

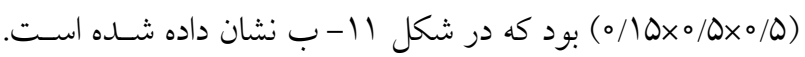

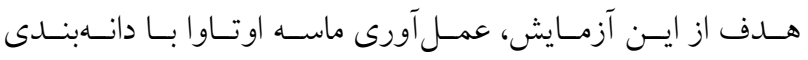

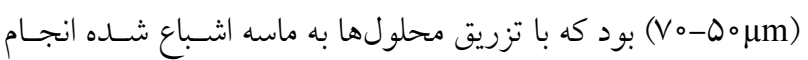
مىشد. فرايند MICP در دو مرحله انجام شد. مرحله اول شـامل

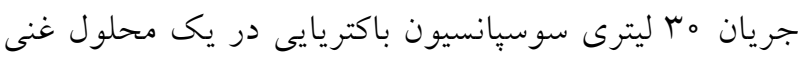

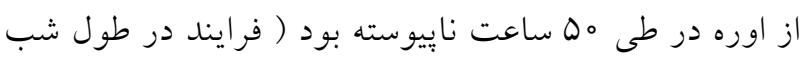

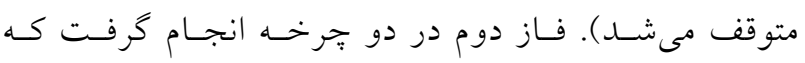

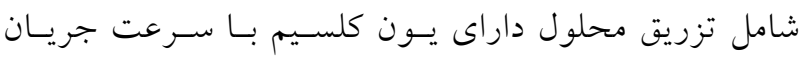

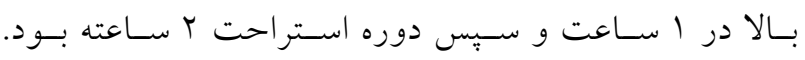
جرخه اول در جهـت جريـان تزريست بـاكترى، درحسالى كـه

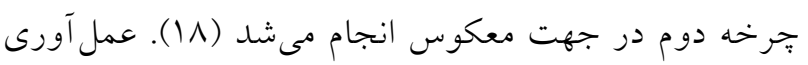
يكنواخت و همكن تحت شر ايط ميكروبى بسيار فعال انجـام

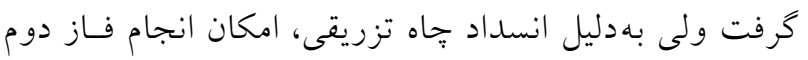

$$
\text { تزريق ميسر نشد. }
$$

كومز و همكاران (9) يك مطالعه ميدانى در استفاده از

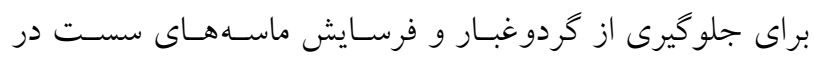

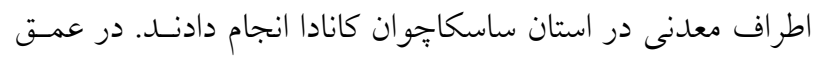

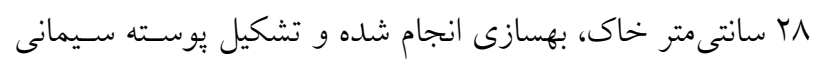

نقاط مىشد از جمله دلايل ذكر شده براى توجيه اين نـاهمخنى در اين آزمايشها بود. يكى ديخر از آزمايشهاى ميدانى انجام شده توسط ون بِن

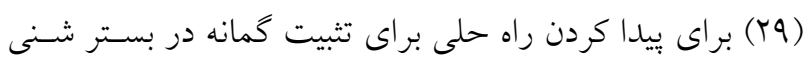

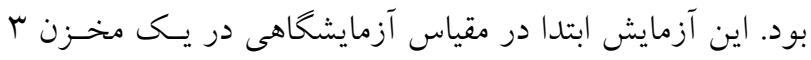

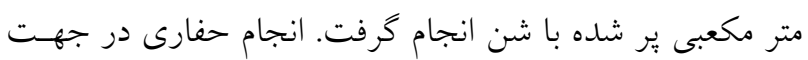

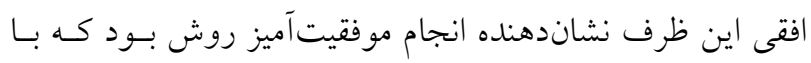

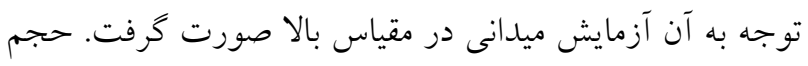

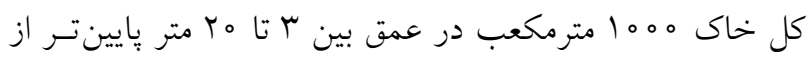

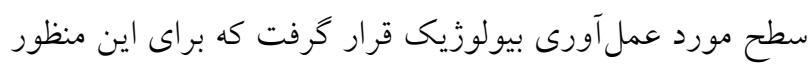

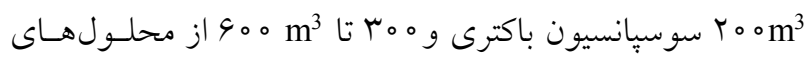

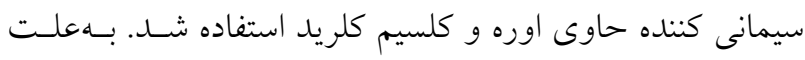
آزاد شدن يونهاى آمونيوم، آبهاى زيرزمينى آلوده شده بـ با ايسن

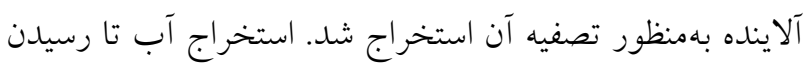

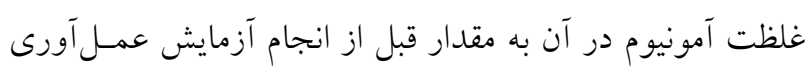

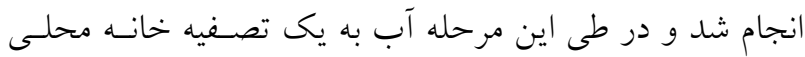

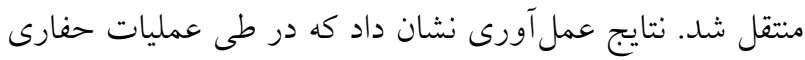
يايدارى لايه شنى حفظ شده و لوله گذارى خط كَاز نيـز بــدون

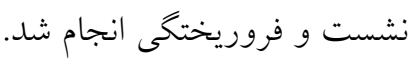

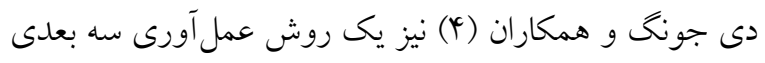

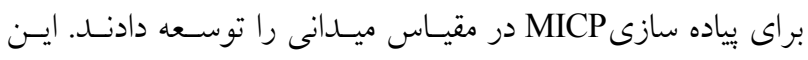

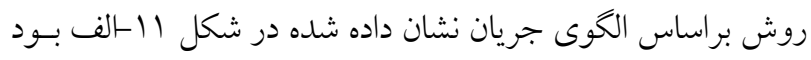




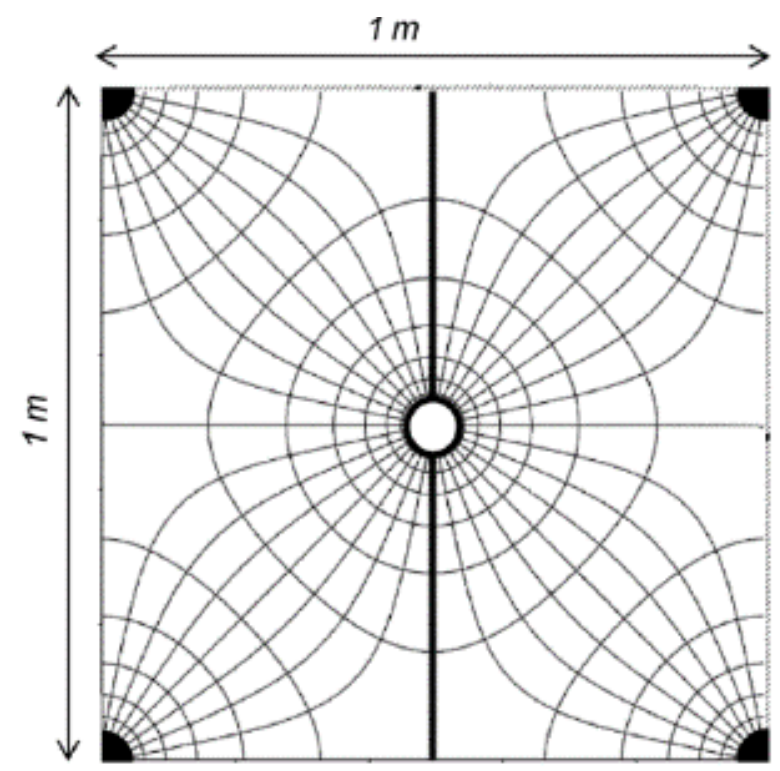

ب) خطوط جريان و خطوط يتانسيل براى منطقه تحت عمل آورى

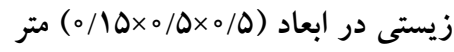

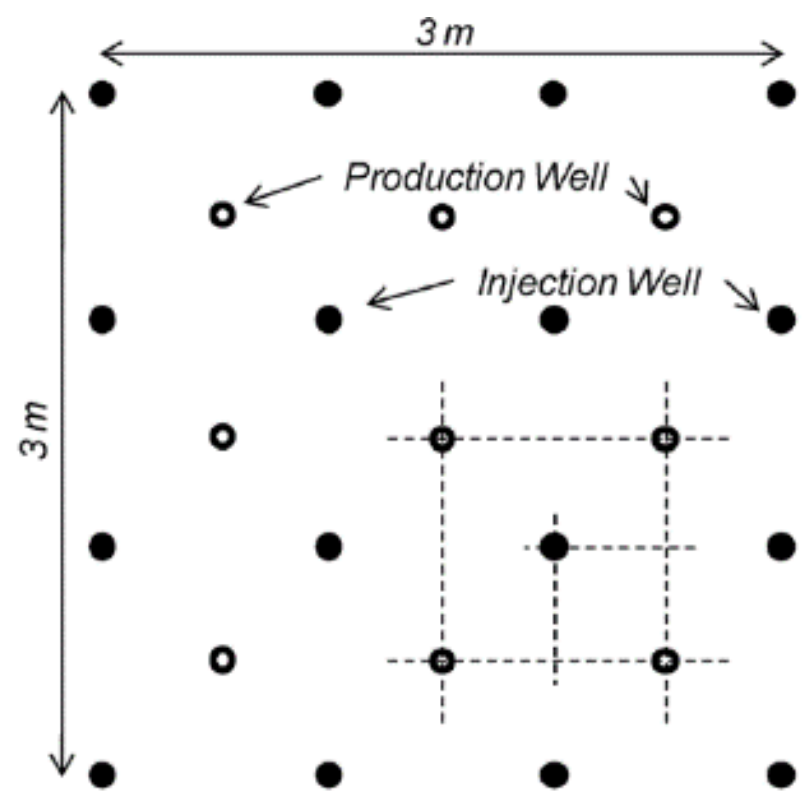

الف) طرح الخوى جريان شامل جاهكهاى

تزريق و استخراج

شكل 11. الكوى تكرارى ينج نقطهاى طراحى شده توسط دى جونگ و همكاران (Y)

آميزى از بيو كلسيس براى عمـل آورى و بهسـازى خـاك ماسـهاى

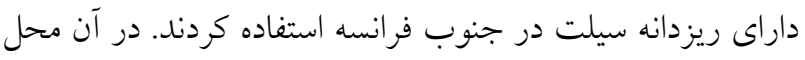

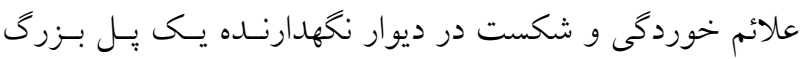

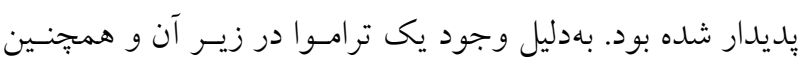

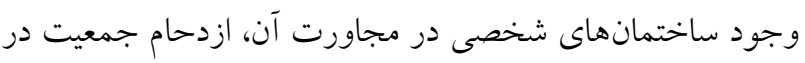
محل مذكور زياد و همجنين سطح دسترسى به آن بسيار كم بـود.

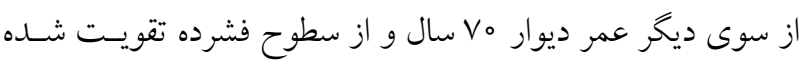

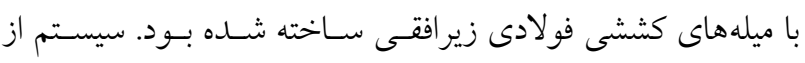

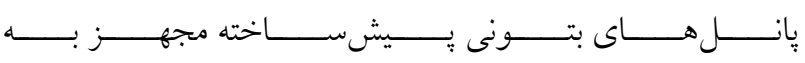

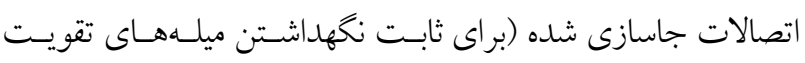

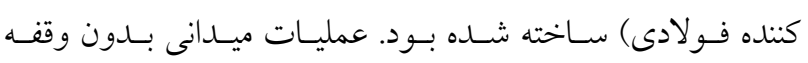

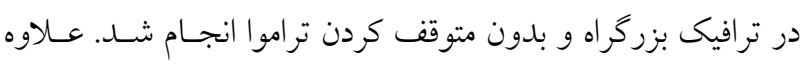

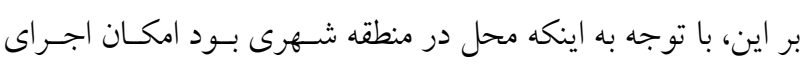

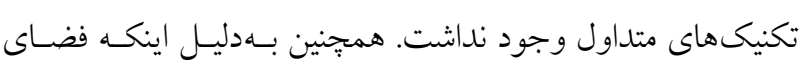

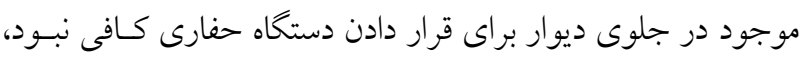

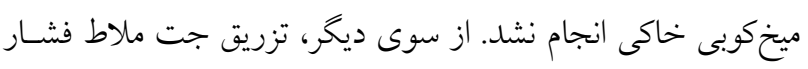

شده با ضخامت r/ه سانتى متر مقاومت در برابر فرسـايش را

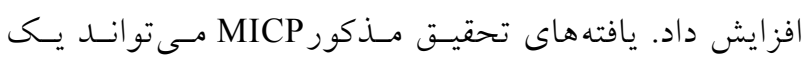
روش اميدوار كننده براى جلو گيرى از فرسـايش در مقيـاس دئس بزرى تر باشد. نتايج همجنين نشان داد كه استفاده از محلول

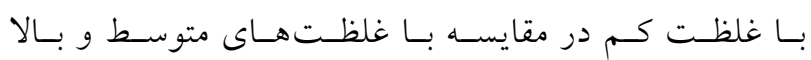

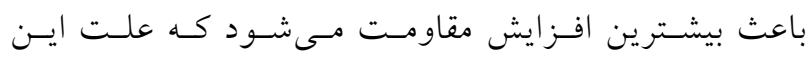
موضوع مى تواند با همخنى توزيع رسوب در كل نمونه مرتبط باشد (9) ب (9) سولتانج باجى (Soletanche-bachy) يك ييمانكار فرانسـوى،

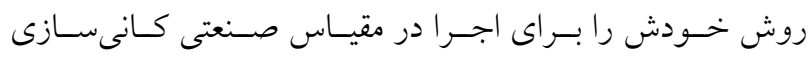

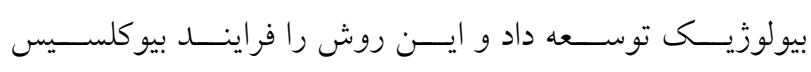

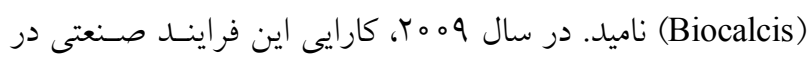

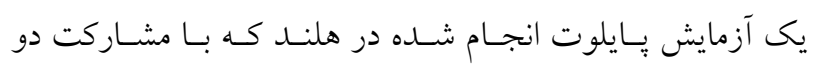

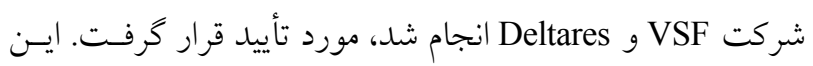

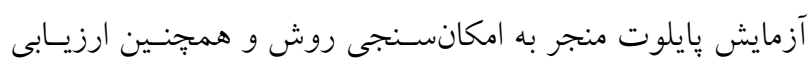

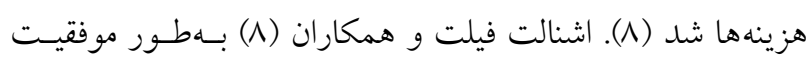



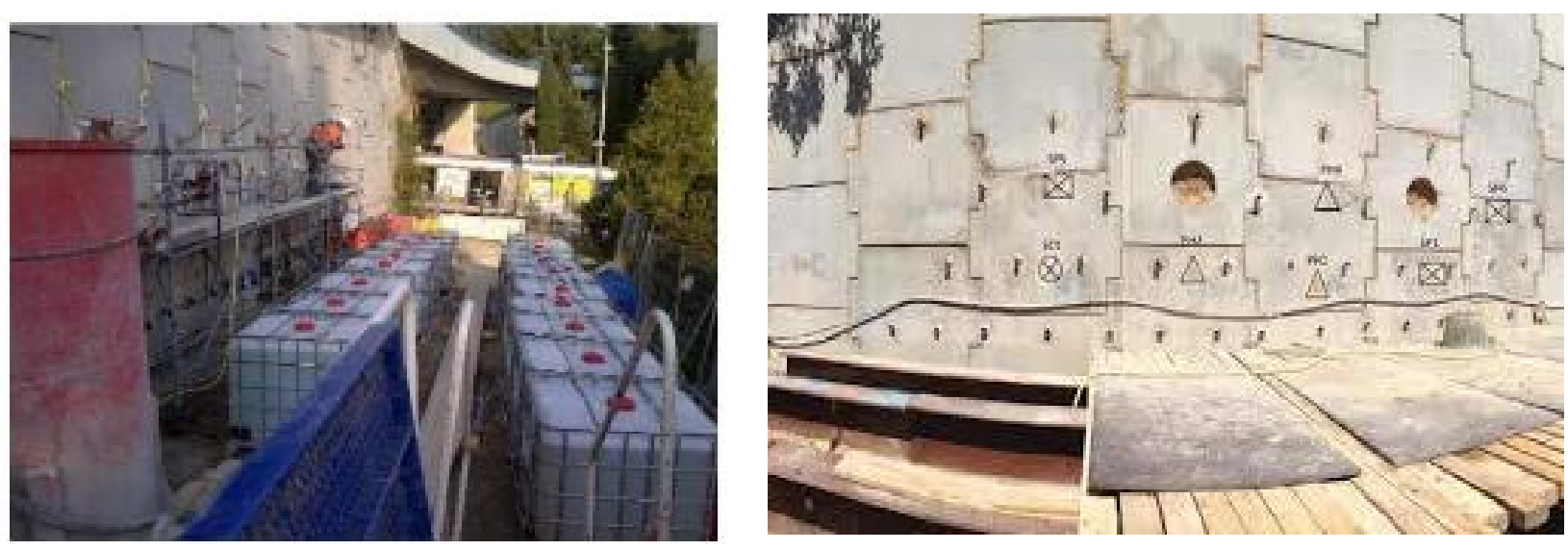

شكل rا. مقاومسازى ديوار نغهدارنده خاك با استفاده از روش بيو كلسيس در مقياس ميدانى (^)

بالا با توجه به امكان ايجاد خطرات بِايدارى در سـازه فـراهم نبـود. مىشود.

محدوديتها و جالشهاى روبهرو در كـاربرد ميـدانى روش زيستى و بيشنهادها

تكنيكهاى مختلفى براى بهبود عملكرد اين روش در مقياس متر استفاده شده است. اخر جهه بيشرفتهايى در اين عرصه از

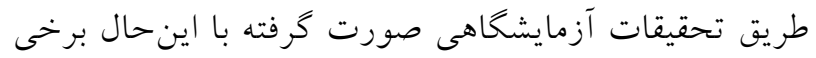

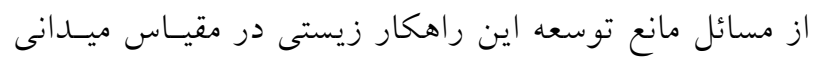

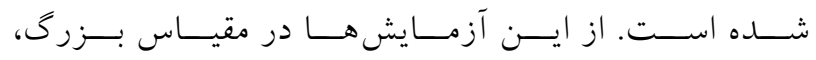

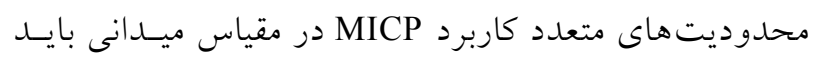
مورد توجه قرار كيرد:

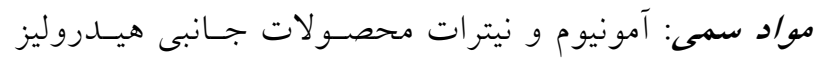
اوره هستند. توليد غلظتهاى بـالاى ايسن تركيبـات، اتـرات

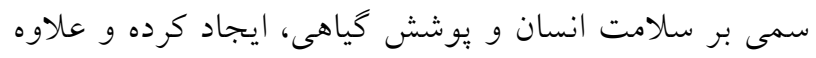

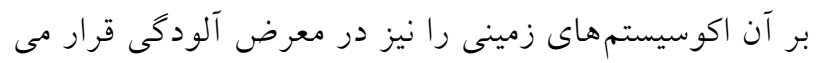

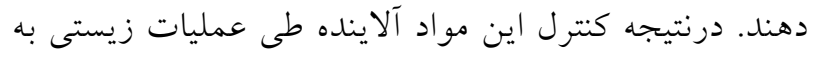
لحاظ رعايت استانداردهاى قانونى زيستمحيطى ضرورى به نظر مىرسد (YI). حجم قابل توجهى از واكنشهاى شيميايى و محلولهاى ميكروبى در طول فرايند MICP بهخصوص در

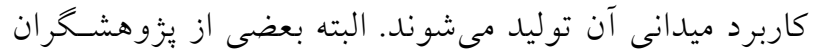

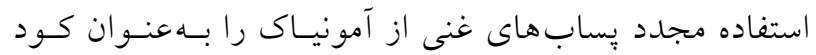

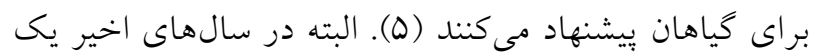

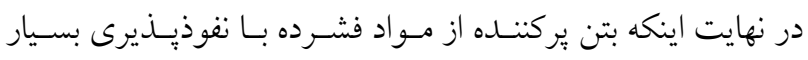

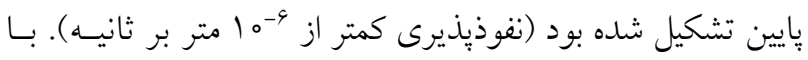

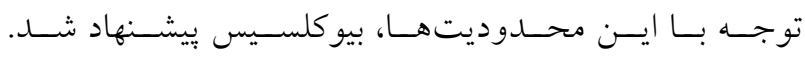

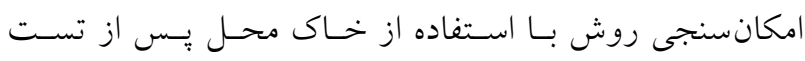

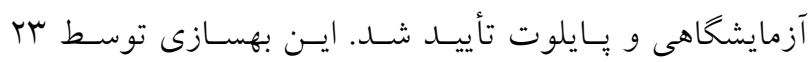
ديواره افقى با عرض ه متر در ب خط تزريـق انجـام شــ كـهـ داراى زهكشى در پايه ناحيه تزريق بود (شكل r I). حجم كل

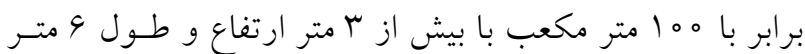

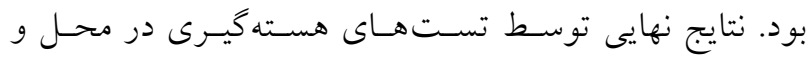
برشـيومترى (Coring and pressiometric tests) بــــــآورد

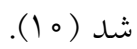

اين آزمايشها قابليت انجام روش مقاومسازى ديوار را تأييد

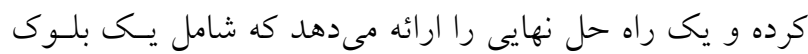

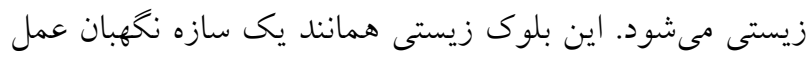

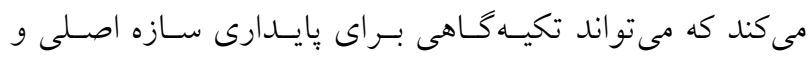

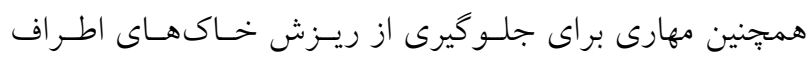

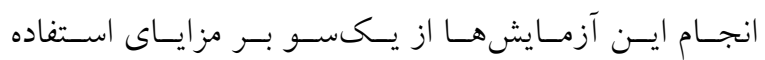

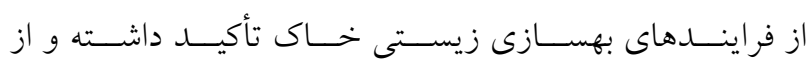

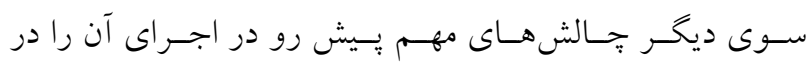

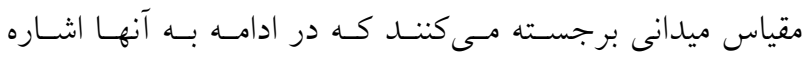


امكان سنجى: پار امترهايى مانند سرعت جريـان تزريـق، تعـداد،

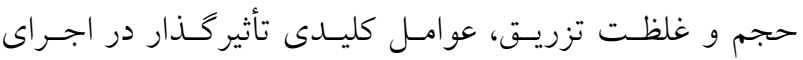
موفقيت آميز MICP هستند. ايسن بارامترهـا بايســ در آزمايشــاه مورد بررسى قرار بخيرند كه اين مسئله مى تواند زمانبر و هزينه بر باشد. اين در حالى است كه در استفاده از تكنيكهاى متداول

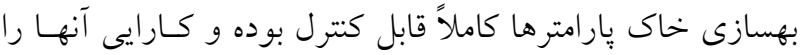
در طول سالها اثبات شده است. مزيت استفاده از فنـاورىهـاى بهسازى زيستى خاك اين است كه استفاده از آن طبيعى بـوده و

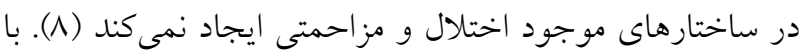

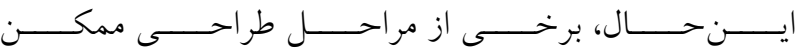
است براى افزايش آكاهى و آموزش در صنعت مورد نياز باشـد. از سوى ديخر مطالعات آمـارى شـامل كنتــرل دقيـق اطمينـان /

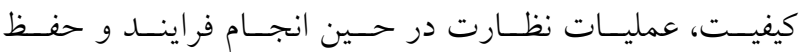

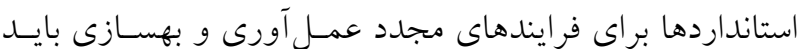

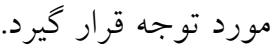
عملكرد: مدلهايى براى بهينهسازى اثرات زمـان و هزينـهـ شـــهـ با هدف اجراى بهسازى زيستى در محل ارائه شده است (9). بـا

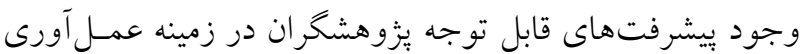

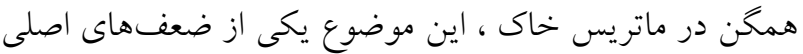

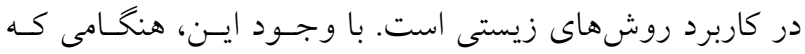

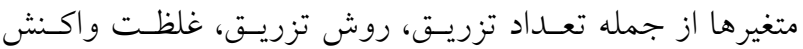

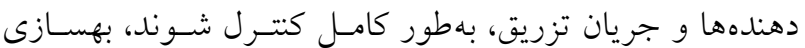

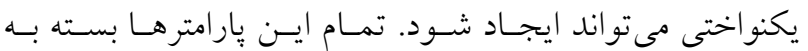
شرايط ميدان، نقطه هدف كذارى شده و نتايج اوليسه در مقيـاس آزمايشخاهى تعيين مىشوند. ماندكارى: بهسازى زيستى براى يكى كاربرد خاص نيازمند دوند دوام

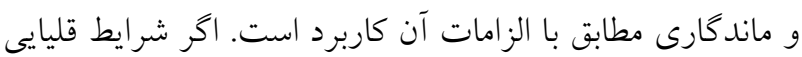

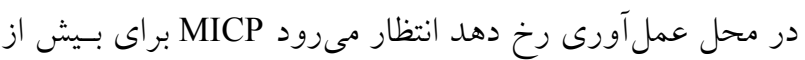

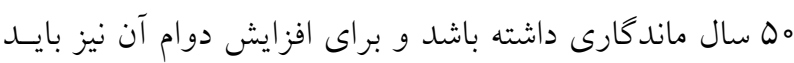

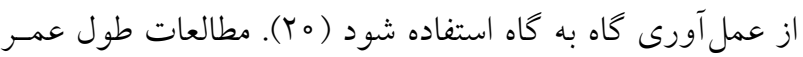

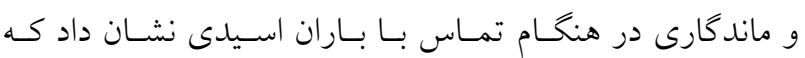

روش جديد براى رسوب بيولوزيك كربنات كلسيم با استفاده

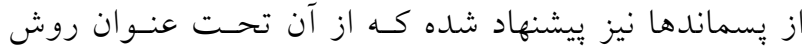

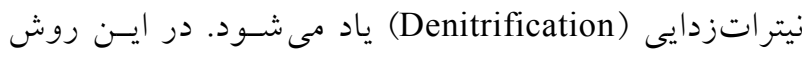
همراه با روند كاهش نيترات بهمنظـور توليـــــــاز نيتـروزن، اسيدهاى جرب به كربنات تبديل مىشوند. در روش نيترات-

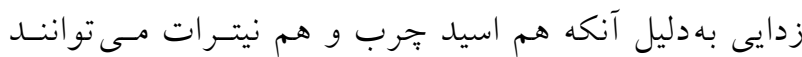
به بورت نمك كلسيم وارد سيستم شـوند نيـازى بــه اضـافه كردن نمك كلسيم به خاك نيست. در ضـمن در ايسن روش مى توان باكترىها را بهصورت درجـا در خـاك رشـد داد. از روش نيتراتزدايى براى توليد كـاز در خـاك بـراى كـاهش خطر روانكر ايسى و اسـفاده از فاضـلابهــاى غنسى از مـواد

غذايى براى ايجاد رسوب استفاده شده است (VV و r r). هزينه: هزينه كلسيم و اوره بالاتر از سيمان معمولى بوده كـهـ

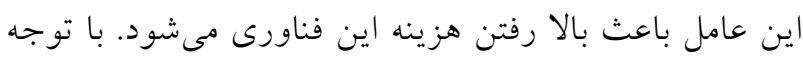

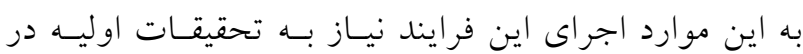
مقياس كوجّى و آزمايشى قبل از ارتقا به مقياس ميدانى دارد

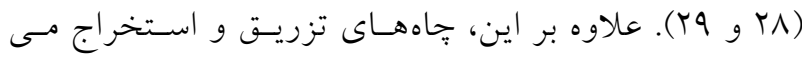

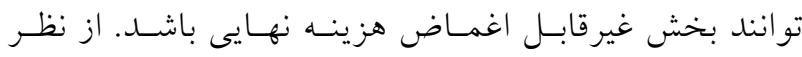

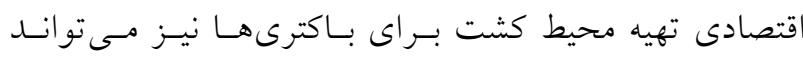
باعنوان ديكر عامل محدود كننده در كاربرد فنـاورى محسوب شـود بـهــورى كـهـ اسـتفاده از MICP در تثبيـت شنهاى روان بر اساس روش ارائه شده در كار ملكى كـاكلر

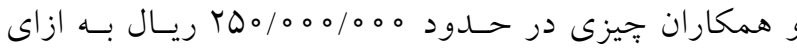

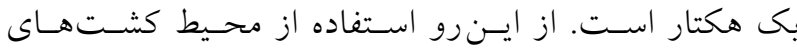
صنعتى ارزانقيمت مانند ملاس و يا عصـاره خيسـانده ذرت مى تواند راهكارى براى كاهش هزينـه لمش (Corn steep liquor)

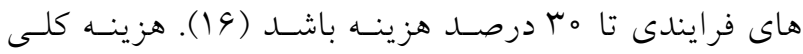
روش MICP (مواد، تجهيزات و نصب) در خاكهاى اشسباع

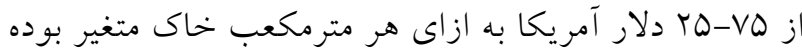

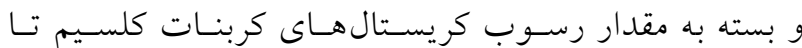

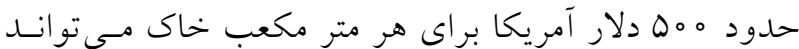

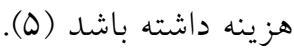


جدول ا. خلاصه محدوديتها و جالشهاى استفاده از روش زيستى و راهكار يشنهادى براى غلبه بر آنها

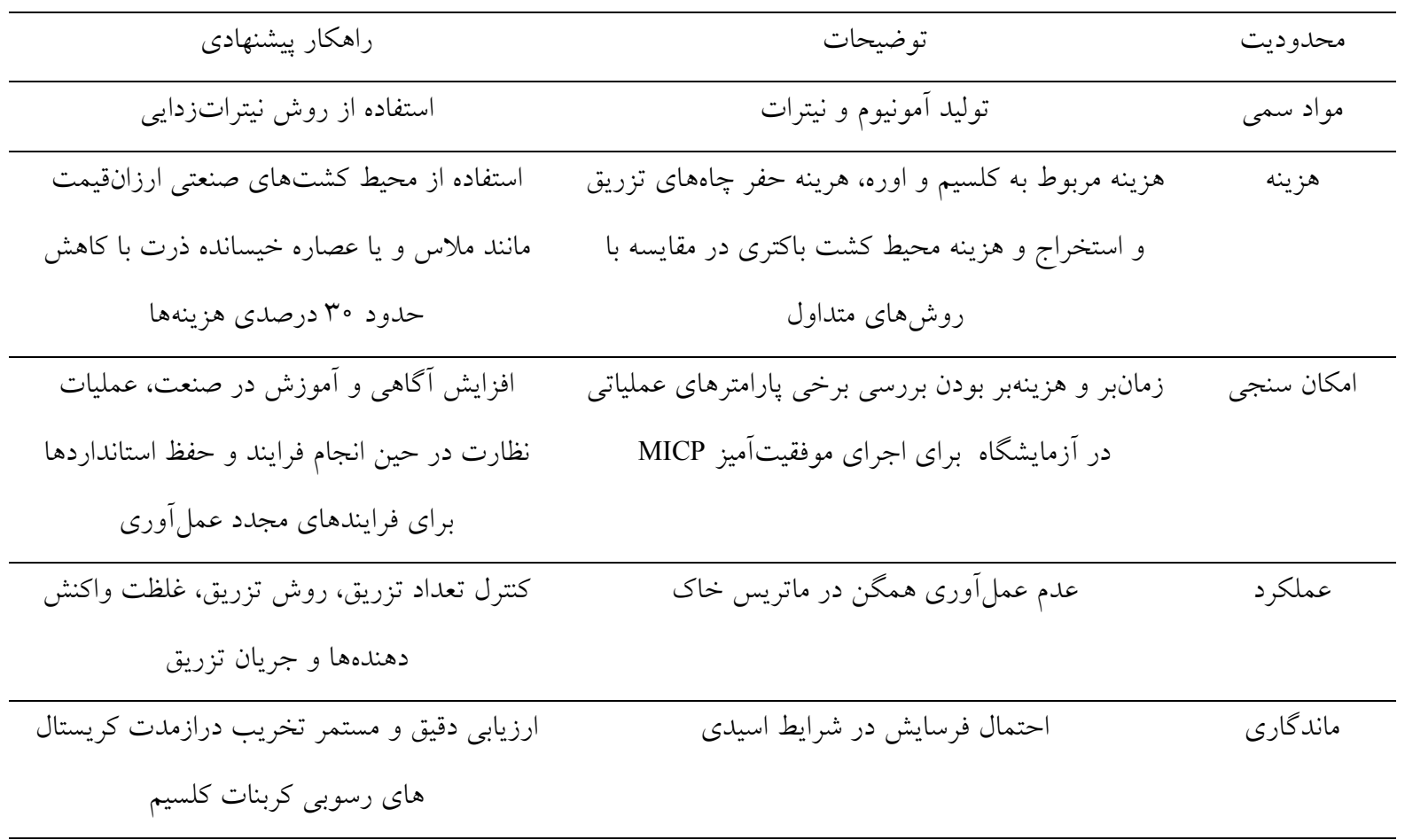

فرسايش شديدى رخ نمى دهد. تنها يس از جريان باليتر بـاران نتيجه گيرى روشهاى اصلاح زيستى خـاك در ها سـال كذشـته افـزايش

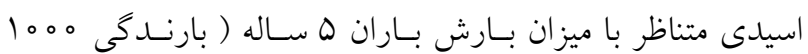

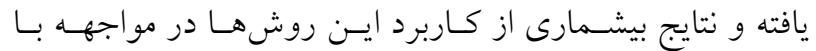

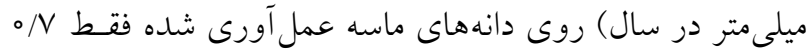
مسائل زئوتكنيك از قبيل بهينهسازى روشهاى زيستى، عوامـل

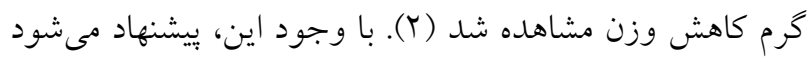

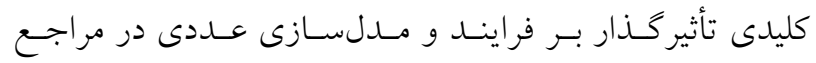

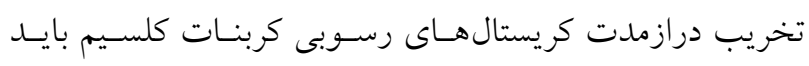

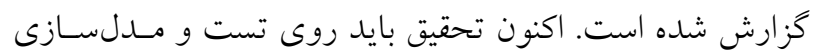

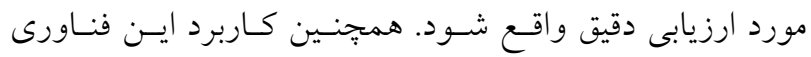

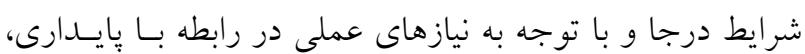

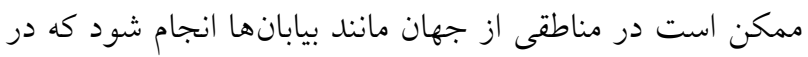

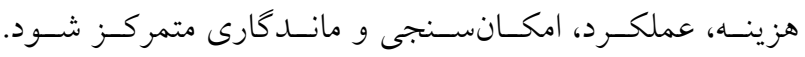

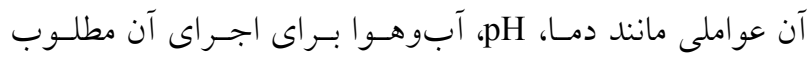

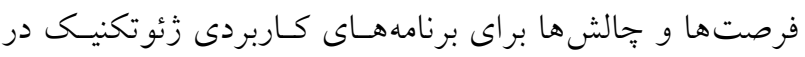

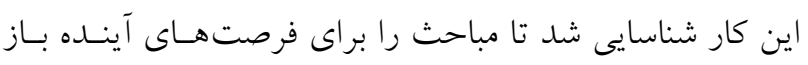
است. محدوديتهـا و جــالشهـاى استففاده از روش زيستى و

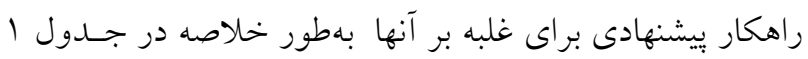

\section{منابع مورد استفاده}

1. Al-Thawadi S. 2008. High strength in-situ biocementation of soil by calcite precipitating locally isolated ureolytic bacteria. PhD Dissertation, Murdoch University.

2. Cheng, L., R. Cord-Ruwisch and M. A. Shahin. 2013. Cementation of sand soil by microbially induced calcite precipitation at various degrees of saturation. Canadian Geotechnical Journal 50: 81-90.

3. De Jong, J. T., B. M. Mortensen, B. C. Martinez and D. C. Nelson. 2010. Bio-mediated soil improvement. 
Ecological Engineering 36: 197-210.

4. De Jong, J. T., M. B. Fritzges and K. Nüsslein. 2006. Microbially induced cementation to control sand response to undrained shear. Journal of Geotechnical and Geoenvironmental Engineering 132: 1381-1392.

5. De Jong, J., B. Martinez, T. Ginn, C. Hunt, D. Major and B. Tanyu. 2014. Development of a scaled repeated fivespot treatment model for examining microbial induced calcite precipitation feasibility in field applications. Geotechnical Testing Journal 37: 424-435.

6. De Muynck, W., K. Cox, N. De Belie and W. Verstraete. 2008. Bacterial carbonate precipitation as an alternative surface treatment for concrete. Construction and Building Materials 22: 875-885.

7. De Muynck, W., K. Verbeken, N. De Belie and W. Verstraete. 2010. Influence of urea and calcium dosage on the effectiveness of bacterially induced carbonate precipitation on limestone. Ecological Engineering 36: 99-111.

8. Filet, A. E., J. -P. Gadret, M. Loygue and S. Borel. 2012. Biocalcis and its applications for the consolidation of sands. Grouting and Deep Mixing 1767-1780.

9. Gomez, M. G., B. C. Martinez, J. T. DeJong, C. E. Hunt, L. A. Delaming, D. W. Major and S. M. Deworatzek. 2015. Field-scale bio-cementation tests to improve sands. Proceedings of the Institution of Civil Engineers-Ground Improvement 168: 206-216.

10. Haouzi, F. Z. and B. Courcelles. 2018. Major applications of MICP sand treatment at multi-scale levels: A review. In: Conference Proceeding of GeoEdmonton, Edmonton, Canada.

11. Harkes, M. P., L. A. Van Paassen, J. L. Booster, V. S. Whiffin and M. Van Loosdrecht. 2010. Fixation and distribution of bacterial activity in sand to induce carbonate precipitation for ground reinforcement. Ecological Engineering 36: 112-117.

12. Jiang, N. -J., K. Soga and M. Kuo. 2016. Microbially induced carbonate precipitation for seepage-induced internal erosion control in sand-clay mixtures. Journal of Geotechnical and Geoenvironmental Engineering 143: 04016100.

13. Karol, R. H. 2003. Chemical Grouting and Soil Stabilization, Revised and Expanded. Crc Press, Boca Raton

14. Maleki-Kakelar, M. and S. Ebrahimi. 2016. Up-scaling application of microbial carbonate precipitation: optimization of urease production using response surface methodology and injection modification. International Journal of Environmental Science and Technology 13: 2619-2628.

15. Maleki-Kakelar, M. M., S. Ebrahimi and M. Hosseini. 2016. Improvement in soil grouting by biocementation through injection method. Asia-Pacific Journal of Chemical Engineering 11: 930-938.

16. Maleki-Kakelar, M., S. Ebrahimi, F. Asadzadeh and M. E. Tabrizi. 2016. Performance of microbial-induced carbonate precipitation on wind erosion control of sandy soil. International Journal of Environmental Science and Technology 13: 937-944.

17. Maleki-Kakelar, M., S. Ebrahimi, F. Asadzadeh. and M. E. Tarbizi. 2016. Evaluation of the Efficiency of Microbial Induced Carbonate Precipitation For Loose Sand Dunes Fixation. Iranian Journal of Soil and Water Research 47: 407-415. (In Farsi)

18. Martinez, B. 2012. Experimental and numerical upscaling of MICP for soil improvement. PhD Dissertation, University of California, Davis, CA, USA.

19. Mitchell, J. K. and J. C. Santamarina. 2005. Biological considerations in geotechnical engineering. Journal of Geotechnical and Geoenvironmental Engineering 131: 1222-1233.

20. Montoya, B. and J. Dejong. 2013. Healing of biologically induced cemented sands. Geotechnique Letters 3: $147-$ 151.

21. Mujah, D., M. A. Shahin and L. Cheng. 2017. State-of-the-art review of biocementation by microbially induced calcite precipitation (MICP) for soil stabilization. Geomicrobiology Journal 34: 524-537.

22. Ng, W. -S., M. -L. Lee, S. -L. Hii, W. -S. NG, M. -L. Lee and S. -L. Hii. 2012. An overview of the factors affecting microbial-induced calcite precipitation and its potential application in soil improvement. World Academy of Science, Engineering and Technology 62: 723-729.

23. Ozdogan, A. 2010. A study on the triaxial shear behavior and microstructure of biologically treated sand specimens. PhD Dissertation, University of Delaware, Newark, USA.

24. Rebata-Landa, V. 2007. Microbial activity in sediments: effects on soil behavior. PhD Dissertation, Georgia Institute of Technology, Atlanta, USA.

25. Stabnikov, V., M. Naeimi, V. Ivanov and J. Chu. 2011. Formation of water-impermeable crust on sand surface using biocement. Cement and Concrete Research 41: 1143-1149.

26. Van Beek, V., J. Lambert, M. Blauw, P. De Louw and E. Faassen. 2008. Application of BioSealing for saltwater seepage reduction. In: 10th International Conference on Soil-Water System, Milano, Italy.

27. Van Der Star, W. R., E. Taher, M. P. Harkes, M. Blauw, M. C. Van Loosdrecht and L. A. Van Paassen. 2009. Use of waste streams and microbes for in situ transformation of sand into sandstone. In: Proceedings of International Symposium on Ground Improvement Technologies and Case Histories, Singapore, 9-11. 
28. Van Paassen, L. 2009. Biogrout, ground improvement by microbial induced carbonate precipitation. PhD Dissertation, Delft University of Technology, Delft, Netherlands.

29. Van Paassen, L. 2011. Bio-mediated ground improvement: from laboratory experiment to pilot applications. GeoFrontiers 2011@sAdvances in Geotechnical Engineering, ASCE 4099-4108.

30. Van Paassen, L. A., C. M. Daza, M. Staal, D. Y. Sorokin, W. Vav der Zon and M. Van Loosdrecht. 2010. Potential soil reinforcement by biological denitrification. Ecological Engineering 36: 168-175.

31. Whiffin V. S. 2004. Microbial $\mathrm{CaCO}_{3}$ precipitation for the production of biocement. PhD Dissertation, Murdoch University.

32. Whiffin, V. S., L. A. Van Paassen and M. P. Harkes. 2007. Microbial carbonate precipitation as a soil improvement technique. Geomicrobiology Journal 24: 417-423. 


\title{
ente \\ Field Scale Application of Microbial Induced Carbonate Precipitation in Soil Improvement: Challenges and Opportunities
}

\author{
M. Maleki-Kakelar* and M. Yavari ${ }^{1}$
}

(Received: January 1-2019; Accepted: August 3-2019)

\begin{abstract}
Biocementation through microbial induced carbonate precipitation (MICP) is a recently developed new branch in geotechnical engineering that improves the mechanical properties of bio-treated soils. The potential application of MICP to handle problems such as liquefaction and erosion has been established; this technique offers an environmentally friendly, cost-effective and convenient alternative to traditional soil improvement approaches. Nevertheless, in spite of the widespread demonstration of the process at laboratory scale, few field and practical applications have been implemented to assess the efficiency of the biochemical process. Therefore, this paper presents a review of the utilization of MICP for soil improvement and discusses the treatment process including the key constituents involved and the main affecting factors, especially in field scale applications. The major contribution of this research is to identify the main parameters restricting the application of this method on site. Finally, technical and commercial progress in the industrial adoption of the technology and the main challenges that are ahead for the future research prior to real practical application are briefly discussed.
\end{abstract}

Keywords: Biocement, Urease, Microbial Induced Carbonate Precipitation, Field scale

1- Department of Chemical Engineering, University of Zanjan, Zanjan, Iran.

*: Corresponding author, Email: mmaleki@znu.ac.ir 